\title{
Advances in Directly Amplifying Nucleic Acids from Complex Samples
}

\author{
Faye M. Walker ${ }^{1}$ and Kuangwen Hsieh ${ }^{2, *}$ \\ 1 Raytheon Company, Waltham, MA 02451, USA; faye.m.walker@raytheon.com \\ 2 Department of Mechanical Engineering, Johns Hopkins University, Baltimore, MD 21218, USA \\ * Correspondence: khsieh4@jhu.edu
}

Received: 26 August 2019; Accepted: 26 September 2019; Published: 30 September 2019

\begin{abstract}
Advances in nucleic acid amplification technologies have revolutionized diagnostics for systemic, inherited, and infectious diseases. Current assays and platforms, however, often require lengthy experimental procedures and multiple instruments to remove contaminants and inhibitors from clinically-relevant, complex samples. This requirement of sample preparation has been a bottleneck for using nucleic acid amplification tests (NAATs) at the point of care (POC), though advances in "lab-on-chip" platforms that integrate sample preparation and NAATs have made great strides in this space. Alternatively, direct NAATs - techniques that minimize or even bypass sample preparation-present promising strategies for developing POC diagnostic tools for analyzing real-world samples. In this review, we discuss the current status of direct NAATs. Specifically, we surveyed potential testing systems published from 1989 to 2017, and analyzed their performances in terms of robustness, sensitivity, clinical relevance, and suitability for POC diagnostics. We introduce bubble plots to facilitate our analysis, as bubble plots enable effective visualization of the performances of these direct NAATs. Through our review, we hope to initiate an in-depth examination of direct NAATs and their potential for realizing POC diagnostics, and ultimately transformative technologies that can further enhance healthcare.
\end{abstract}

Keywords: nucleic acid testing; sample preparation; disease diagnostics; bubble plot

\section{Introduction}

Nucleic acid amplification tests (NAATs) have become indispensable tools in biology and medicine. For example, for infectious diseases diagnostics, NAATs are generally faster, more sensitive, and more specific than the current gold standard of culture-based techniques. In fact, a number of DNA- and RNA-based diagnostics are now recommended by the US Food and Drug Administration (FDA) for infectious diseases such as human immunodeficiency virus (HIV) [1,2]. Bringing NAATs to the point of care (POC), and particularly to resource-poor settings, is envisioned to revolutionize healthcare. Unfortunately, many NAATs require access to expensive, specialized equipment and a degree of expertise that is highly unlikely to be found in decentralized laboratories. As an additional challenge, these tests typically require an extraction step to isolate DNA or RNA from blood, urine or sputum, and a purification step to eliminate contaminants from the sample matrix that can confound the actual detection procedure (Figure 1). These procedures necessitate expensive instrumentation and can add up to several hours to sample-to-answer results, which further restricts the use of NAATs within centralized laboratories. 


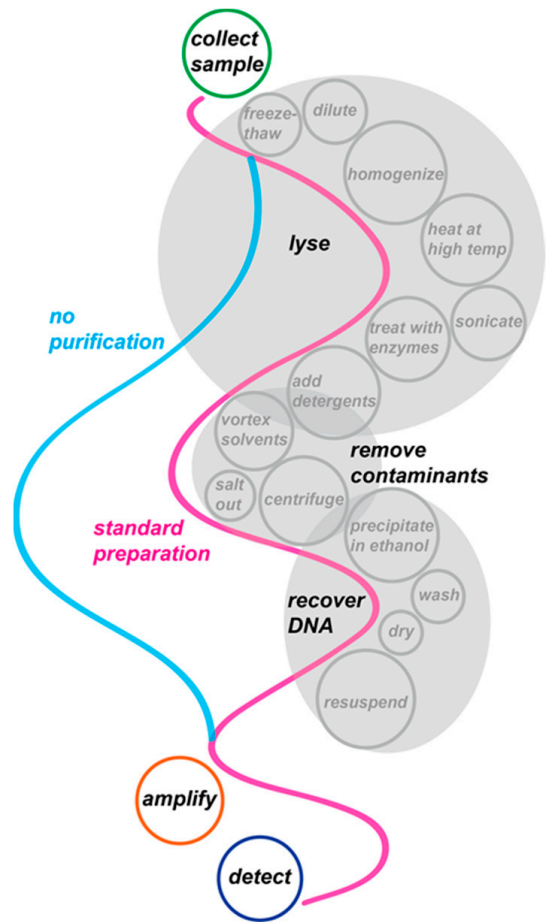

Figure 1. Direct nucleic acid testing is much more convenient and streamlined than the three-step method with preparatory techniques. In a typical extraction experiment, buffer with lytic agents is added to dilute the sample and homogenized with a mixer. Sonication creates pressure waves that burst the cells in mechanical lysis. Lysozyme enzymatically destroys cells, and is removed from the reaction with vortexing and centrifugation in a phenol/chloroform phase separation. The DNA is precipitated in fresh ethanol and the resulting mixture is washed to remove excess contaminants. Excess liquid is removed so that the DNA can be resuspended in an appropriate buffer.

Many groups have attempted to develop portable, integrated, microfluidics-based platforms to increase the functionality of diagnostic sensing and analysis [3-5], and some of these have even been commercialized (e.g., bioMerieux's NucliSENS easyQ tests, TwistDx's TwistAmp kits, and Enigma Diagnostic's MiniLab). These platforms present breakthrough technologies for rapid, cost-effective, and user-friendly diagnostics. While it remains to be seen whether these systems are simple and error-free enough for developed and developing settings, they demonstrate the feasibility of implementing existing nucleic acid amplification methods for POC use [6-9].

An alternative approach to time-consuming and cumbersome sample preparation is performing NAATs directly from complex samples (Figure 1). The advantage of traditional amplification technologies, such as PCR with real-time spectroscopic or mass spectrometry detection, is that the results are highly specific and quantitative. However, these sensing platforms are expensive and require prior extraction of genetic material from the sample.

Direct NAATs are advantageous when complicated, costly laboratory apparatuses are not available. They not only reduce the time, labor, and technical constraints of molecular testing, but also bring the additional benefit of standardizing results [10]. Indeed, a growing number of groups are developing such "direct" NAATs. Most notably, the Alere i Influenza A\&B assay became the first FDA Clinical Laboratory Improvement Amendments (CLIA)-waived nucleic acid-based test [11] in January 2015. As the Alere i system requires no front-end nucleic acid extraction, and can be used outside of traditional laboratory sites [12-16], its development and CLIA-waived status provide strong support for further development of direct assays that can minimize or even bypass sample preparation.

Thus motivated, we present the current state of direct assays and platforms that achieve nucleic acids detection and analysis from clinically-relevant, complex samples but with either minimal or 
even no sample preparation procedures. We surveyed the literature from 1989-2017 and came across a significant number of works that reported NAATs from bodily samples (e.g., blood-based liquids, oral samples, swabs) without the complex steps generally involved in sample preparation. This meant discarding the works that depended on sophisticated instruments and operations that are labor-, time-, and cost-intensive, such as enzymatic (proteinases), chemical (acids, detergents), or physical (temperature shock, mechanical disruptions) treatments. Then, we describe examples whereby data visualization can be used to reveal the connections between the robustness, sensitivity, and efficacy of technologies developed for direct DNA- and RNA-based tests. It is our hope that in reviewing technologies such as these, and presenting these promising early findings in an information-rich and accessible fashion, we can help to accelerate the development of approaches that make POC nucleic acid testing rapid, accurate, simple, and affordable.

\section{Methods}

In order to find relevant articles with data on NAAT parameters, we performed literature searches from December 2014 to February 2018.

\subsection{Literature Search}

We searched Google Scholar with a combination of search terms. These followed a formula of combining a descriptor (e.g., "point-of-care"), an amplification technology (e.g., "LAMP" OR "loop-mediated isothermal amplification") and a sample matrix (e.g., "blood"). References of previously published reviews, as well as those included in original studies, were checked for possible candidate articles.

\subsection{Record Screening}

Articles were initially screened on the title, and secondly on the abstract. Any articles that relied on microfluidic platforms or commercialized extraction devices were excluded. Publications that required complex pre-processing with enzymatic treatment or chemical purification were not selected. Studies were included if they involved direct amplification and detection of genetic material from one of six representative sample types: blood, dried blood spot, serum and plasma, saliva and sputum, swabs, urine, and stool. The full text of appropriate articles was read to extract the necessary information.

\subsection{Data Abstraction}

From each of the 174 published works surveyed, we extracted and recorded data that corresponded to test performance. There are many parameters that cannot be ignored when considering NAATs: accuracy, specificity, user-friendliness, training requirements, and so on. As such, we provide an extensive examination of nucleic acid template specificity (including single or multiplexed reactions), amplification methodologies (enzymes, operating temperatures, and amplification technology), and user-friendliness (storage considerations, pretreatment requirements, and physical involvement) in Supplementary Table S1.

In addition, we have classified assays that can feasibly be completed without extensive training or high-end instrumentation as "direct," whereas those with greater labor or equipment demands (e.g., freezers, high-speed centrifugation, or incubation for multiple hours) are deemed "semi-direct." Specifically, the "semi-direct" assays have the following exceptions to a simple laboratory setup: alternating between two or more incubation temperatures (other than room temperature), relying on enzymatic activity, or requiring more than a brief, low-speed $(<100 \times g)$ centrifugation. Methods categorized as "semi-direct" face some hurdles to implementation as an on-site service for patient care. What these tests do offer is a way to deliver actionable results that can link diagnosis to treatment. With appropriate conversion from requirements for highly trained staff and sophisticated tools to easy-to-use methods, "semi-direct" procedures will meet the requirements for POC diagnostic devices. 


\subsection{Visualization Process}

We found certain parameters could be distilled into numerical data, yielding particularly useful insights when examining different tests. We have devised three major criteria that are indicative of each platform's robustness, sensitivity, and clinical efficacy:

1. Tolerance to the sample of interest-ideally, the assay should be able to detect its target against a high concentration of background contaminants. We note that, although sample dilution sometimes provides a convenient way of permitting amplification, doing so inevitably reduces the limit of detection (LOD). Most NAATs analyze only a fraction of the sample volume. Sample dilution therefore increases the likelihood of false negative results, especially when the samples already have low target concentrations.

2. LOD_by foregoing sample preparation, one generally sacrifices the opportunity to concentrate bulk samples, reducing the limit of detection and making sensitivity an important consideration.

3. Clinical evaluation-recognizing assays that have been validated with clinical samples.

Finally, we sought to devise a visual strategy that would clearly and quickly communicate the importance of our criteria, compare the wide range of assays, discover trends in the data, and reveal patterns in a single glance. Specifically, the essential information of the 174 reviewed publications is presented quantitatively in a single plot. Relevant values are standardized and communicated in terms of visual attributes of position, size, shape, and color.

We have found it particularly useful to visualize the data as "bubble plots." In a bubble plot, numerical values from three parameters are simultaneously visualized via the two axes and the size of the circular marker. Different categories can also be grouped according to the color of the markers. In our case, we can readily display the essential information (e.g., sample tolerance, LOD, and instances of clinical testing) of related procedures to discern those that enhance test performance.

\section{Brief Overview of Isothermal Amplification Techniques}

In our survey, we came across eight DNA- and RNA-based testing techniques. As expected, PCR (and reverse transcription PCR, or RT-PCR) has been the predominant technique. Notably, a number of isothermal amplification techniques have also been used to develop direct NAATs. Herein, we provide brief overviews of these lesser known isothermal amplification techniques.

\section{1. $L A M P$}

While PCR is the most commonly reported method of amplification, there is an increasing number of isothermal amplification technologies that can be truly used at the POC. The single reaction temperature enables the use of less costly, complicated instruments than for thermal cycling tests. Loop-mediated isothermal amplification (LAMP) is one such widely researched, developed, and characterized method [17]. Amplification employs a strand-displacing polymerase and two or three pairs of primers: one that is sacrificed to linearize the template, and one or two others that prime the DNA synthesis to produce concatenated, cauliflower-like products [18]. As with PCR, LAMP has been modified to target RNA as reverse-transcription (RT)-LAMP [19].

LAMP has been compared to PCR in other ways as well, including applications with bacterial, viral, fungal, and parasitic assays. Not only has the specificity and sensitivity been equivalent to that of PCR, the robustness of LAMP to certain preparations of serum, swabs, and blood has shown it to be more tolerant to inhibitors than PCR [8].

\subsection{NASBA}

The nucleic acid sequence-based amplification (NASBA) method is unique in its ability to amplify single-stranded RNA directly [20]. This is most desirable for targeting RNA viruses and for transcriptome analysis [8]. The continuous, homogeneous, isothermal process relies on RNA 
polymerase, RNase, and reverse transcriptase. First, the reverse transcriptase creates a double stranded RNA:DNA hybrid from the RNA template; next, the original RNA is destroyed; a DNA duplex is synthesized; then, the polymerase can transcribe RNA from the DNA. Each new RNA molecule can repeat the cycle for exponential amplification.

NASBA has been applied to a wide-ranging set of research problems, including HIV diagnosis during the AIDS epidemic of the 1990s and automated, real-time, clinical tests in blood with the modern NucliSENS (bioMerieux, Inc., Durham, NC, USA) or in urine with the APTIMA assay (Hologic, San Diego, CA, USA). NASBA is also used outside of the commercial sector with systems to monitor viruses in serum [21].

\section{3. $S D A$}

The strand displacement amplification (SDA) technique is based upon the abilities of a restriction enzyme and a DNA polymerase. A primer containing a recognition sequence for the restriction enzyme binds to its complementary, single stranded DNA target. After extension by the polymerase, the restriction enzyme nicks the unmodified strand of the double-stranded hemiphosphorothioate recognition site. DNA polymerase then extends the $3^{\prime}$ end of the nick, displacing the downstream strand. The end result is exponential target amplification from the displaced strands, which serve as targets for new reactions.

SDA is not complex, but it does suffer from sensitivity issues in the presence of background DNA. The best way to overcome off-target amplification, and hence reduce false-positives, is to use simple pretreatment procedures like those that have been developed for detection with the BDProbe-Tec (Becton Dickinson Microbiology Systems, Sparks, MD, USA) and in-house systems for urine [22].

\subsection{RPA}

Recombinase polymerase amplification (RPA) avoids thermal cycling by using three core proteins that operate optimally between $37-40{ }^{\circ} \mathrm{C}$ [23]. The first protein, recombinase, binds to primers that recombine with a duplex target for strand displacement. The second, a single-stranded DNA binding protein, attaches to the displaced strand before a strand-displacing polymerase copies the DNA from the primer onwards for exponential amplification.

One of the requirements for RPA technology is sequence-specific detection. This avoids the problem of primer artifacts that add to background fluorescence with nonspecific, intercalating dyes. With its specific readout and rapidity ( $<20 \mathrm{~min}$ to results) as two main features, RPA provides an alternative to the time-consuming processes of culturing and bacterial genotyping when testing for pathogens [7].

\subsection{SIBA}

Strand invasion based amplification (SIBA) is another amplification process that relies on recombinase activity. In SIBA, there is a separate recombinase substrate that is inserted between two primer-binding sites. The duplex peripheral to this insertion site is separated, enabling the primers to bind. DNA polymerase can then extend the template from the bound primers. This use of an invading substrate, one that is neither consumed nor included in the extension of DNA, is advantageous because it abolishes primer artifacts. SIBA can therefore be used to reliably detect low copy numbers of pathogens-other isothermal methods generate non-specific amplification products in the absence of target DNA [24]. Going further, the specificity of SIBA enables multiplexing for the detection of templates that differ by as little as two bases [25].

\section{6. $M D A$}

Multiple displacement amplification (MDA) is a technique that exploits the strand displacement, proofreading, and polymerase activity of the $\$ 29$ bacteriophage DNA polymerase [26]. The highly processive polymerase uses random primers to amplify an entire genome. MDA is therefore well-suited for whole genome amplification from crude biological samples, which can be followed by single nucleotide polymorphism (SNP) testing and genotyping [8]. 


\section{7. $H C R$}

The concept of hybridization chain reaction (HCR) [27]—an enzyme-free, room-temperature method-relies on a DNA trigger to initiate amplification. The initiator interacts with two stable DNA hairpins to create nicked double helices. Amplification of this initiation event continues until the hairpins are depleted. HCR is a useful assay for detecting short DNAs, such as human immunodeficiency virus type 1 (HIV-1) in serum [28].

\section{Analysis of Surveyed Direct NAATs}

\subsection{Growing Prevalence of Direct NAATs}

Time-series plots offer an effective means for showing the growing prevalence of direct NAATs. Specifically, within each sample type, we plotted the number of clinical samples that have been analyzed by direct NAATs from 1989 to 2017 (Figure 2). Here, we also divided the data into two cohorts based on whether samples were subjected to PCR (Figure 2, black) or isothermal amplification techniques (Figure 2, red). As expected, we saw an overall rise in the number of clinical samples analyzed via NAATs with minimal or no sample preparation over the analyzed period. Across all six sample types, we observed sharp spikes, which indicate studies of high numbers of clinical samples. Based on the sample type, swab samples had been most analyzed, while urine and stool samples had been least analyzed. Within each sample type, after an initial lag, we saw a notable rise in the use of isothermal amplification techniques. This first became apparent as early as 2003, several years after the advent of LAMP in 2000, and twelve years after the introduction of NASBA [20]. PCR-based systems emerged within five years of the technique's inception in 1986 [29], and PCR largely continues to dominate the realm of nucleic acid testing. The one notable exception is seen in our time-course of blood testing, where isothermal techniques have surpassed PCR and RT-PCR in terms of the number of assays performed on whole blood samples.

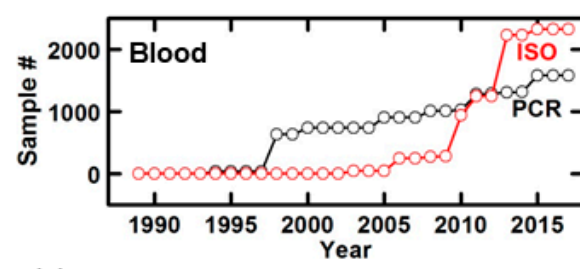

(a)

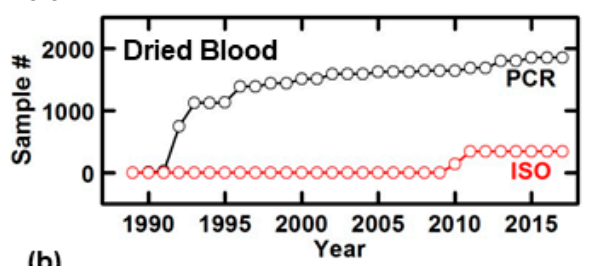

(b)

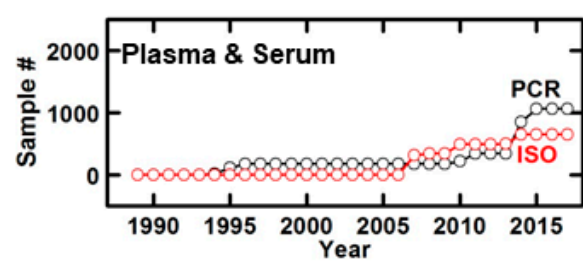

(c)

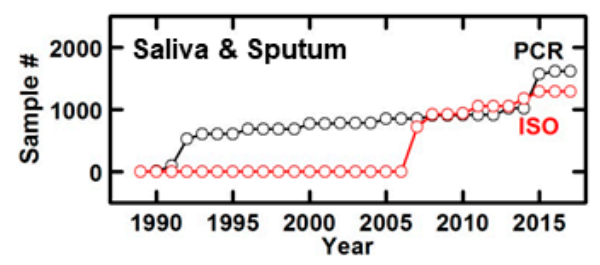

(d)

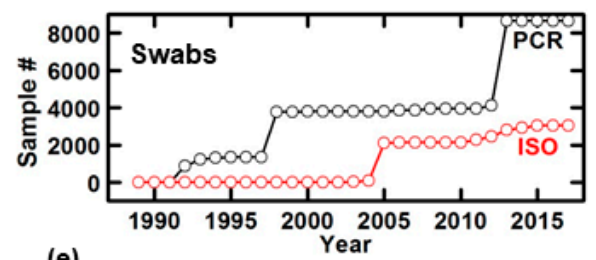

(e)

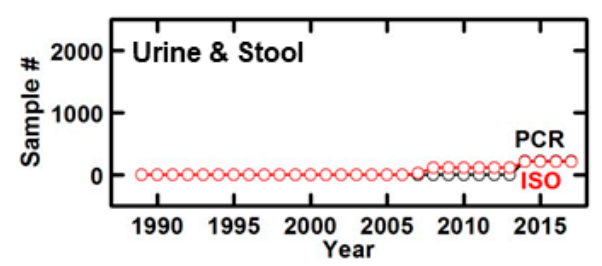

(f)

Figure 2. Time-series data for direct nucleic acid diagnostics according to accrued number of samples tested. Individual plots of number of clinical samples over time are subdivided according to sample matrix as follows: (a) whole blood, (b) dried blood, (c) plasma and serum, (d) saliva and sputum, (e) oral, dermal, and conjunctival swabs, and (f) urine and stool. 


\subsection{Direct NAATs for Whole Blood}

Because blood contains circulating nucleic acids, cells, and over 20,000 different proteins, it offers an abundance of biomarkers for disease detection. Molecular diagnostics in blood are useful for detecting specific DNA or RNA sequences from a range of bacterial, toxic, and viral infectious agents. Platforms for hepatitis and human immunodeficiency virus [30], Staphylococcus aureus [31], and Plasmodium species are just a few of the most-used systems enabling rapid diagnostics in whole blood.

Blood-based testing generally demands sophisticated detection instruments or extensive preparation to recover inhibitor-free and high-purity DNA. Not all inhibitory blood components are known [32], but heme compounds, anticoagulants, and immunoglobulin G (IgG) can all interfere with amplification reactions by inhibiting DNA polymerase activity [33] or chelating necessary cofactors [34,35]. Although a wide range of bloodborne viruses, bacteria, and parasites can in principle be detected with nucleic acid testing, extraction- and purification-free means of detecting these pathogens are not currently commercially available.

We have visualized the general trends of direct and semi-direct nucleic acid testing in blood as a function of the LODs (Figure 3). The $\%(v / v)$ of blood tolerated in a reaction is plotted against the LOD in $g$ of template, with the number of clinical samples encoded as the area of the bubble. We have also assigned colors to indicate the type of amplification technology. It is evident that many studies have achieved high sensitivity in detecting their target in a low concentration of blood. This shows that nucleic acid testing has great potential for blood-based tests in POC situations where collection volumes are small (e.g., finger pricks) and parasite loads may be low. Those examples from the literature that were not demonstrated on patient samples are considered separately in the plot, and represented by Xs rather than bubble markers. Some of these are purported to have very low LODs that reach below the fg level (Table S1) - it remains to be seen whether such tests will perform with the same extreme sensitivity in a clinical context.

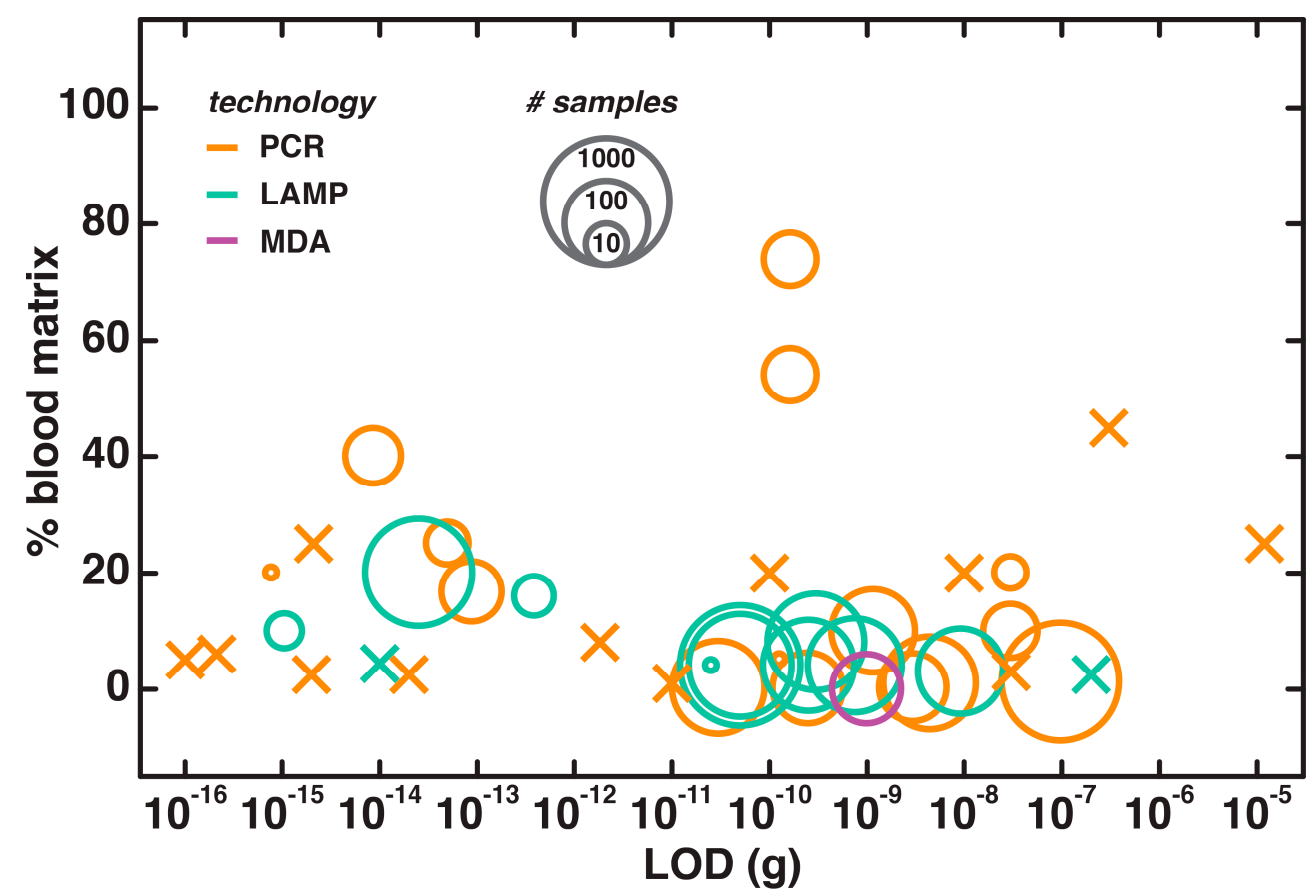

Figure 3. Bubble plot of nucleic acid diagnostics performed in whole blood. Percent concentration $(v / v)$ of blood per reaction in a given procedure is displayed as a function of the limit of detection (LOD) in $g$ of template. The number of patient samples tested is proportional to the log of the marker area, as shown at top, and the testing methodology is indicated by marker color. Cases shown with $\times$ instead of bubble markers illustrate that patient testing was not reported. 
By assessing the PCR- and isothermal-based data, we could obtain some insight into how to optimize these techniques to better tolerate blood as a sample matrix. Several of the semi-direct works with PCR have employed over $50 \%$ blood in a reaction after heat-cold shock [36]. More noteworthy is a truly direct example that relied on the specificity and efficacy of the Phusion polymerase (New England Biolab, Ipswich, MA, USA) to perform PCR in $40 \%$ blood [37]. PCR typically employs the Taq polymerase from Thermus aquaticus. Chemical additives, whether commercially-available cocktails [38,39] or in-house buffers [39-52], allow the Taq family of polymerases to amplify DNA from whole blood. PCR can likewise be optimized through the use of more unconventional polymerases [53-58] and physical heating steps [53,59-64] to reduce the inhibitory effect of blood components. These referenced works offer expedited methods to obtain amplifiable templates with similar sensitivities to chemical-based extraction kits [59]. Though several authors include the use of a centrifuge in the extraction process, these semi-direct methods of template preparation could likely be completed by relying on careful pipette-based transfer of supernatants rather than high-speed centrifugation $[59,63]$.

Most isothermal amplification-based diagnostics in blood make use of LAMP [17], which offers a highly tolerant means of amplification [8]. Simple treatments with heat [59,65-76] or chemicals [73,77-81] can increase the sensitivity of the LAMP or RT-LAMP reaction. Most impressive are the examples of direct amplification of DNA in blood with LAMP-based technologies $[82,83]$ and other isothermal amplification methods like MDA [84]. Some of these assays employ a post-heating centrifugation step, but since Poon et al. have demonstrated that LAMP can be performed directly on heat-treated blood without a spin-down process, this step could likely be avoided in semi-direct processes [68].

Even though these successful examples of simple, direct nucleic acid testing methods highlight the promise of DNA amplification in whole blood, there is an ongoing need for further improvements. No assay has come close to reaching the capacity of Burckhardt et al.'s PCR amplification with Taq polymerase in nearly $80 \%$ whole blood, as demonstrated over 20 years ago in 1994 [36]. The associated treatment method is one of the more technically-involved and time-intensive, demanding 20 cycles of heating and cooling. It remains to be seen whether an isothermal amplification method could equal this tolerance. Perhaps these techniques will make up for their decreased level of tolerance in their ease of use, as evidenced by Suzuki et al. achieving $20 \%$ incorporation of whole blood in LAMP with only a five-minute heating [76].

\subsection{Direct NAATs for Dried Blood}

Dried blood spots offer a convenient alternative for screening for genetic disorders, testing for infectious diseases, and profiling drug metabolism in settings with limited laboratory or storage capabilities. Such samples are typically prepared by spotting whole blood, either from venous blood or a finger prick, onto filter paper [85]. Sampling time is quick, temperature-controlled storage is unnecessary, and biohazard risks are minimized for health care workers [86]. The downside of such samples is that the DNA in the dried blood must be eluted from the paper-based cellular components before it can be amplifiable.

Filter paper has been used as medium to test blood for infectious diseases since the 1940s [87]. From syphilis diagnosis during World War II [88], to infant screening in the 1960s [89], to HIV detection and monitoring in the modern day $[85,90]$, there are important assays with dried blood spots in NAATs. Commercial technologies are even becoming widely available to map, monitor, and survey blood spots from patients infected with malaria or other neglected tropical diseases [74,91]. In a similar manner, the preparation and processing techniques for dried blood samples presented below could open new avenues for disease control and elimination when combined with well-standardized assays for detecting bloodborne pathogens.

As shown in Figure 4, all of the tests we surveyed have been validated with actual dried blood spots. In the most-heavily tested example (720 clinical samples) by Raskin et al., pretreatment with 
heating-cooling cycles and addition of spermidine to the reaction helped boost the efficiency and yield of the amplification [92]. Blood spot-containing filter paper can typically be directly added into a mixture of reagents, though it necessitates overcoming the high background interference of the filter paper and detecting small amounts of dried blood.

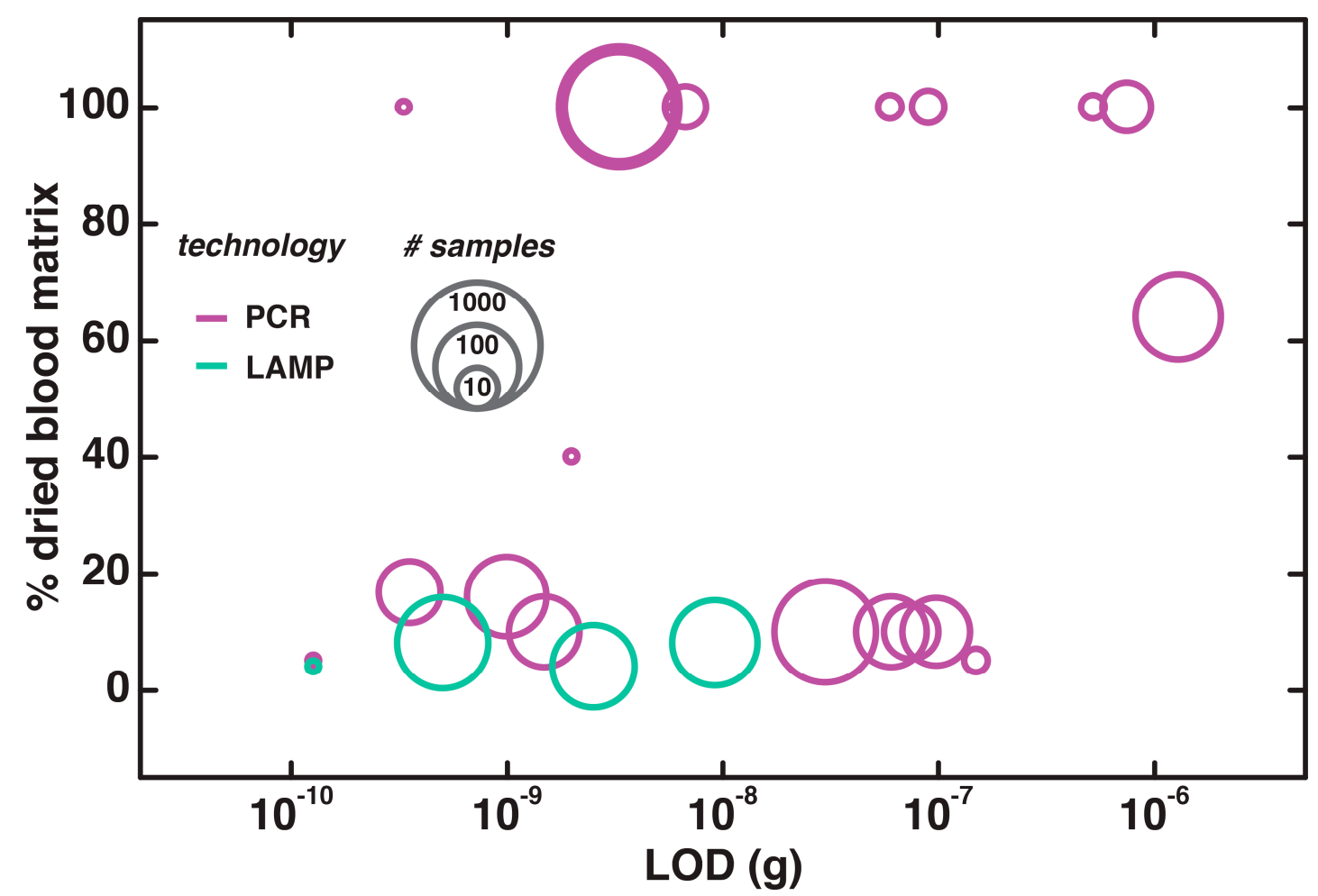

Figure 4. Nucleic acid testing with dried blood spots, with data presented as in Figure 3.

To overcome the background interference from filter paper in directly amplifying dried blood spots via PCR, researchers have bolstered the enzyme's resistance to inhibitors and included various buffer components [47,93]. Pretreatments, such as fixing [92,94-97] or heating [43,98-100], also aid in improving sensitivity and specificity. Even if the procedures are reported as being too lengthy for POC, there are appropriate ways to scale down the waiting period: for instance, an overnight drying period with methanol while under vacuum [98] can be streamlined into a five-minute methanol fix [100]. Most of the approaches to amplify DNA directly in blood spots use eluants-either from commercial kits [51,101], in-house buffers [44,59,102-105], or water [106,107]—to overcome the various difficulties that impede PCR reactions with paper matrices. Buffer-based eluants, in addition to being cost-effective, can achieve even higher sensitivities than standard extraction protocols [105]. Similar preparatory approaches are used for LAMP, wherein heating in water [72,108], phosphate buffered saline (PBS) [59], or sodium dodecyl sulfate (SDS) buffer [74] enables a fast and easy nucleic acid elution with amplification results that are comparable to the conventional gold standard of microscopy $[72,74,108]$.

One of the difficulties in making blood spots suitable for LAMP and PCR is the need to re-suspend the spots in liquid, then filter out the species of interest. The easiest way to address the former problem is through long elution times; the latter, through centrifugation. This makes Taylor et al.'s amplification of Plasmodium spp. DNA directly from clinical filter paper samples such a remarkable achievement for low-resource settings. The combination of an inhibitor-resistant Taq mutant and an enhancer cocktail resulted in a specificity and sensitivity of $100 \%$ for 48 patient samples [47]. All the approaches have interesting characteristics that make them special, but none achieve the ease in use of this assay for malaria. 


\subsection{Direct NAATs for Plasma and Serum}

Blood plasma and serum are widely used for quantitative molecular diagnostics in the areas of clinical decision-making and therapeutic management [109]. Plasma is the pale yellowish fluid that normally holds the blood cells of whole blood in suspension, whereas serum is the remnants of blood plasma after the removal of clotting factors [110]. Circulating DNA in serum and plasma is a biomarker for a diverse array of systemic, infectious, and genetic diseases. These include particular disorders such as diabetes [109] and hepatitis B virus [111].

Refining blood into serum or plasma historically requires expensive equipment for centrifugation or sedimentation. Recovering DNA or RNA from blood-based proteins, nutrients, electrolytes, antibodies (particularly IgG), antigens, hormones, and exogenous substances becomes even more challenging when considering the low relative levels of cell-free or cell-bound nucleic acids [112-114]. More recently, however, paper- or card-based devices [115,116], membrane-based sedimentation [117], and microscale devices for cell differentiation and filtration [118] have made blood separation a single step process at the POC. As such, we include these sample types here.

In assessing nucleic acid testing with plasma or serum, we see that most reactions are performed at sample concentrations in the $20 \%$ range (Figure 5). However, it is important to note that the sensitivity does not necessarily suffer in much more concentrated samples-in Liu et al.'s highly robust two-step amplification process with direct hairpin assembly and HCR-based detection of SNP DNA sequences in $50 \%(v / v)$ serum, they achieved a very low LOD of $100 \mathrm{pg}$ [119]. These plasma/serum-based tests are especially promising for use in real-world contexts, because their clinical relevance is well-documented-18 out of the 24 cases examined here included testing with patient samples.

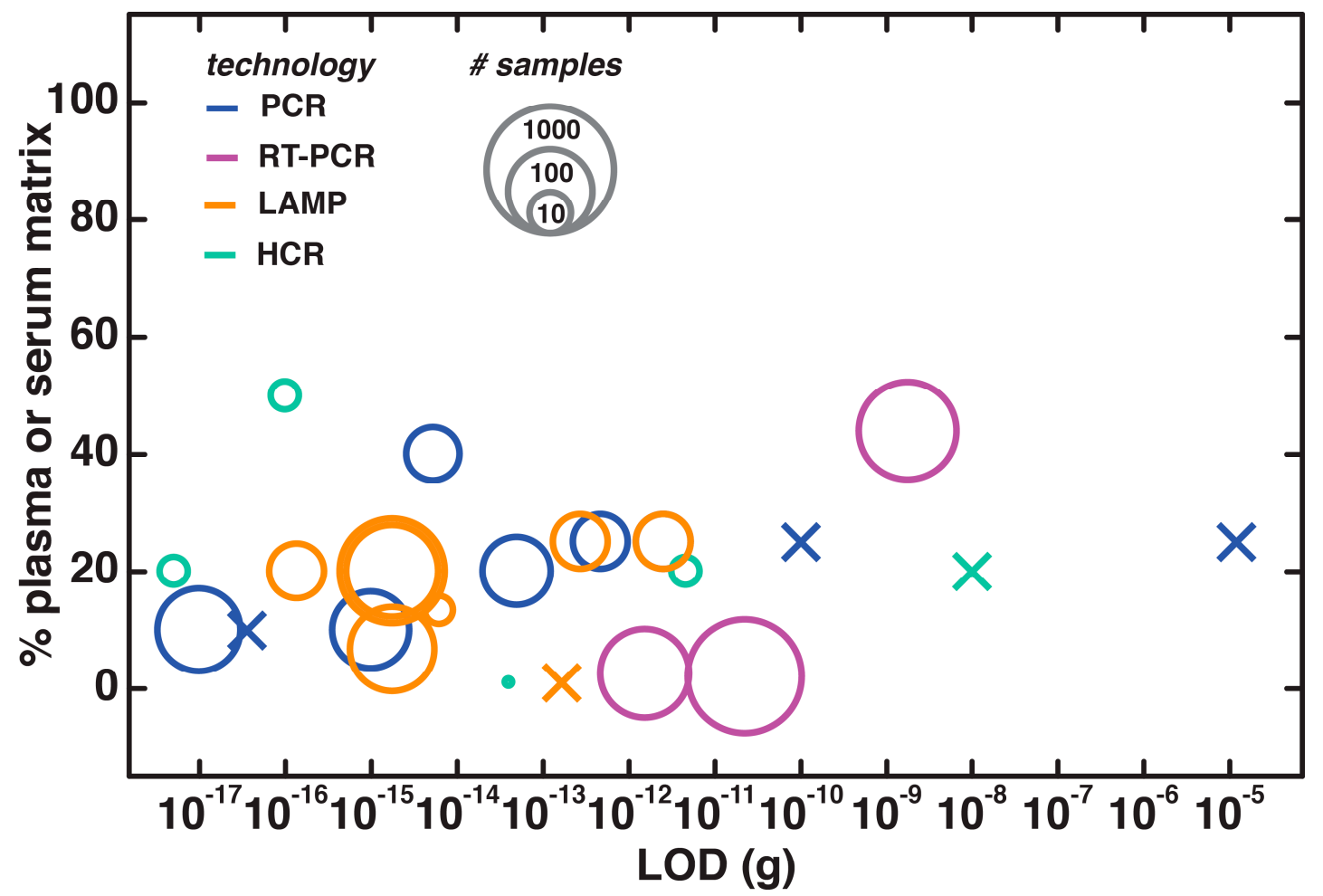

Figure 5. Serum and plasma-based nucleic acid testing, with data presented as in Figure 3.

Researchers have developed convenient PCR assays for both direct and semi-direct testing in blood-based fluids. By using enhanced enzymes, DNA [49,50,67,120] and RNA [121,122] targets have been successfully amplified in plasma and serum. Additionally, heat-based pretreatment can be used to release nucleic acids prior to carrying out amplification [36,60,123-126]. 
The effect of preheating can be seen in LAMP as well. LAMP is generally tolerant to the serum or plasma environment $[120,127]$, but preheating the input sample has been found to have a favorable effect [128-131] that produces up to a 100-fold improvement in sensitivity [132]. This heating also enabled Pardee et al. to detect Zika virus RNA in serum with high sensitivity using NASBA [21]. HCR performs especially well in serum without any pretreatment $[28,119,133-135]$, presumably because the reaction relies on cascaded hybridization events instead of polymerases.

Because plasma and serum contain very low-abundance analytes, nucleic acid tests need to operate with high sensitivity. Fortunately, LAMP-based applications are achieving increasingly low limits of detection. Nijru et al., for instance, demonstrated that their LOD of 1 Trypanozoan parasite/L serum in HAT diagnosis was 100-fold more sensitive than PCR testing. Such methods could still benefit from user-friendly techniques for large-scale processing. Some semi-direct examples presented above include a centrifugation step to collect condensate formed after heating, but could just as easily rely on pipette collection to obviate the need for a high-speed centrifuge. Others might benefit from certain stand-alone modules for plasma and serum separation that could be integrated into a POC workflow $[117,136]$.

\subsection{Direct NAATs for Saliva and Sputum}

Saliva and sputum are abundant and easy to obtain, and are thus attractive samples for diagnostics. Saliva flows into the oral cavities through salivary glands, where blood vessels secrete the same protein and nucleic acid biomarkers as in peripheral blood. In contrast with blood-based samples, saliva sampling does not require trained technicians, presents fewer antigen-associated risks, and can be more easily purified (saliva is $95 \%$ water) [137]. Sputum, a necessary sample for respiratory infections, is mucus from the lower airways. Unfortunately, saliva and sputum are very heterogeneous with respect to the distribution of organisms, chemical composition, and the presence of outside contaminants such as toothpaste, cigarette smoke, coffee, or mouthwash. Technical extraction kits such as RNaqueous and MagMAX (Life Technologies, Grand Island, NY, USA) are often used to eliminate inhibitors and nucleases from oral samples. The viscosity of sputum requires particularly cumbersome protocols for sample preparation: full processing begins with mucolytic agents such as $N$-acetyl- $L$-cysteine (NALC) and dithiothreitol (DTT), disruption of mycobacteria by detergents and proteolytic enzymes, then isolation of target DNA by organic solvents or capture reagents $[138,139]$.

The human salivary microbiome has importance as a diagnostic indicator of oral cancer, oral diseases such as periodontitis, and systemic diseases such as pneumonia [140]. As for sputum, it has become the specimen of choice for detecting tuberculosis [141,142]. NAATs for Mycobacterium tuberculosis have been endorsed by the WHO (World Health Organization) and the FDA for their high accuracy $[143,144]$. The systems introduced below extend the practical usage of sputum for POC testing by reducing the requirements for sputum manipulation.

Most reported nucleic acid testing methods for saliva and sputum show fairly high numbers for patient samples tested, with only two of 30 cases that did not examine clinical specimens (Figure 6). The approaches we examined generally employ dilutions of $20 \%$ or less, and achieve low detection limits. This is critical for avoiding false positives, as the target concentrations in sputum and saliva are small. The lowest LOD achieved-2 fg of Acinetobacter baumannii bacterial gDNA in sputum—required pretreatment with Sputazyme (Kyokuto, Tokyo, Japan) and heat before LAMP analysis [145]. In contrast with blood, the high water content of saliva should make it relatively easy to augment the concentration of matrix that can be employed in an amplification reaction. There are several examples of amplification directly on dried sputum collected via filter cards, which is an especially promising direction for direct testing at the POC if samples need to be stored, handled by multiple clinicians, or reevaluated at later dates $[87,146,147]$. 


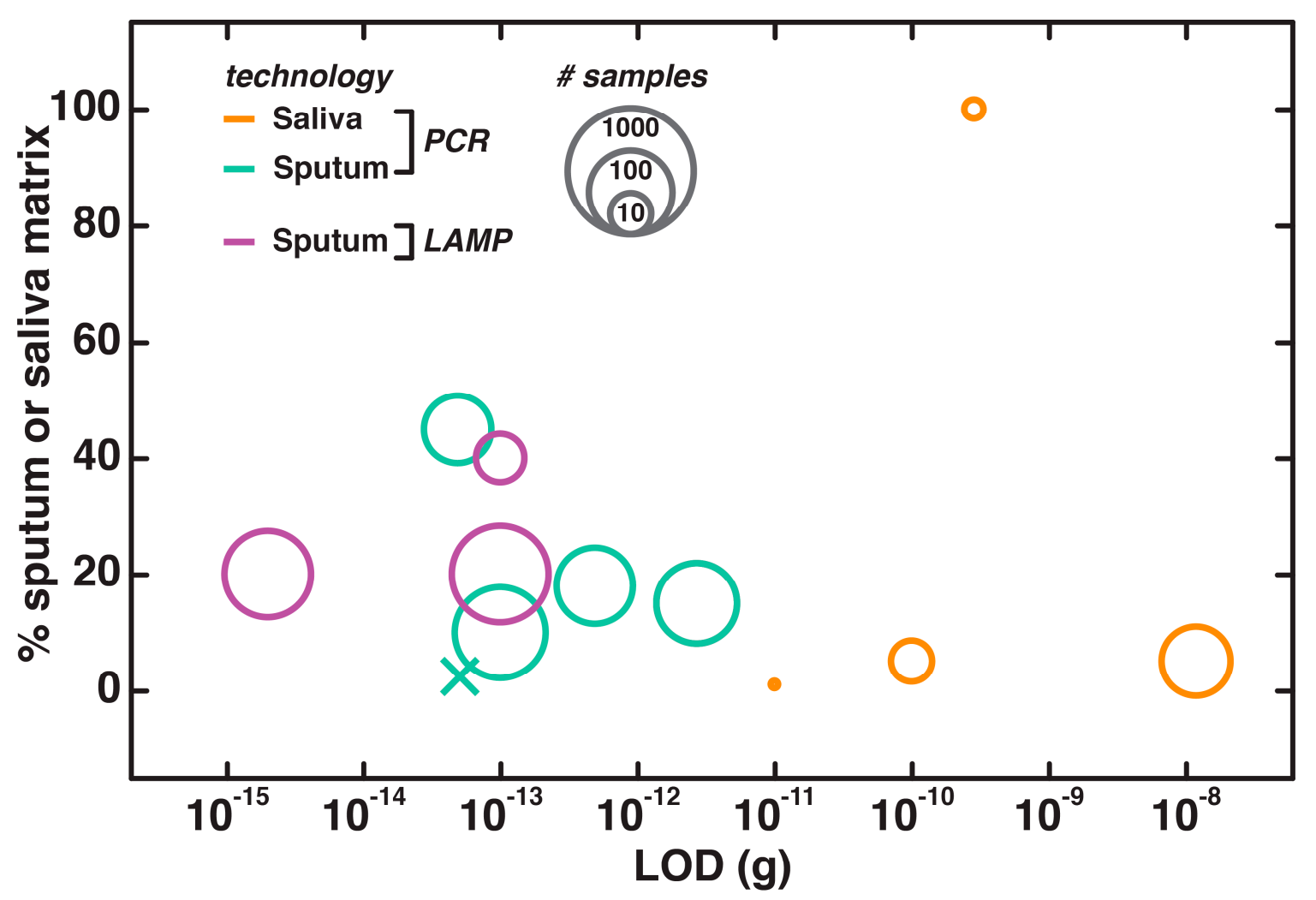

Figure 6. Nucleic acid testing procedures in saliva and sputum, with data presented as in Figure 3.

Amongst the collection of approaches for direct PCR amplification on saliva samples, those that begin with dried saliva swabs fully circumvent DNA extraction, purification, and quantification [93]. Hall et al. added punches of saliva stains directly to the reaction mixture in order to perform STR analysis. Genetic testing in saliva or sputum is often performed directly in liquid samples, and dilution into the reagents is typically sufficient to negate the effect of any inhibitors [148-150], although heat [151] or additives such as polyethylene glycol (PEG), hydroxides, or dithiothreitol (DTT) may be added to further process samples $[42,43,56,145]$. With the broad range of bacterial species present in the mouth (over 600 inventoried), differing in terms of their contributions to health and disease, PCR is very useful for profiling large numbers of bacteria. Some species are recalcitrant to lysing, like Streptococcus. So, instead of relying on bead-beating, phenol treatments, or other steps, Aas et al. applied proteinase $\mathrm{K}$ lysates directly to PCR reagents [140]. Several other groups have followed suit in detecting bacterial taxa in healthy [152,153] and diseased saliva samples [154]. Direct amplification is also possible in the field of LAMP-based diagnostics, as evidenced in testing for Zika [82] and malaria [65]. Du et al. went further than simplifying the sample treatment, a ten-minute heating of Zaire Ebolavirus DNA in saliva, by actually providing a LAMP-to-glucose transduction that can be read out on a handheld glucometer [155].

Designing direct tests for sputum is inherently difficult because many nucleic acid-based methods process samples analogously to culture-based protocols. In this $\mathrm{N}$-acetyl-L-cysteine (NALC)-NaOH method [156], the viscous sputum matrix is liquefied through several buffer exchanges and high-speed centrifugation into a more manipulative sample for testing. An additional concern is decontamination. This is necessary for culture, but also useful to protect the operator from biosafety hazards in molecular testing [157]. Several semi-direct examples based on LAMP [158-160], recombinase polymerase amplification (RPA) [23,161], or PCR [162-166] have adopted this practice.

However, side-by-side comparisons of nucleic acid testing on sputum samples with or without $\mathrm{NaOH}-\mathrm{NALC}$ treatment have indicated that $\mathrm{NaOH}-\mathrm{NALC}$ processing could be removed to enable truly direct protocols for sputum. Mitarai et al. reported that the addition of NALC to a sputum 
specimen prior to extraction had no effect on testing for TB [167]. Furthermore, Tarhan et al. showed that the sensitivity in TB testing was better for sputum samples that were measured directly, rather than after extraction with $\mathrm{NaOH}-\mathrm{NALC}$ [168]. In pursuing alternatives to the lengthy NaOH-NALC method, sputum has been used in PCR after adding mucolytic agents [56,169], diluting in buffer [148], or bead-beating [157] to reduce viscosity. A more aggressive pretreatment, relying on chemical, thermal, and mechanical means of disruption, used heating and centrifugation to detect TB in 548 sputum samples with comparable performance to more expensive molecular-based systems [170]. One particularly noteworthy example of direct testing used LAMP to diagnose tuberculosis at three peripheral laboratories [147]. In the study, LAMP had a sensitivity of 97.9\%, detecting 173 out of 177 smear-negative, culture-positive sputum samples. The authors canvassed the laboratory personnel after they implemented the heating, washing, and filter-tip capture steps before direct amplification to verify that the assay had significant potential to be adopted for routine use.

Several early examples of PCR on sputum samples with Mycobacterium spp. reported sensitivities in the single-digit copy number range. However, the pretreatment methods were quite divergent. Sjobring et al. used long centrifugation and sonication steps, in addition to boiling, to detect down to eight organisms [171]. Sritharan et al. was able to cut down the steps to a $30 \mathrm{~min}$ boiling period, with a resulting LOD of 1 organism [172]. Since these examples in the 1990s, only one technique with a pre-amplification wash and an RPA reaction has been able to match this performance in detecting a single mycobacterium [161]. As far as combining specificity and sensitivity without adding technical difficulty, Priye et al.'s recent multiplexed RT-LAMP detection system for Zika, dengue, and chikungunya achieved LODs of 44 copies/reaction with no need for lysis or extraction [82]. These impressive outcomes from isothermal technologies like RPA and LAMP illustrate that fancy hardware is not necessary for testing modalities to achieve high specificity directly in human samples.

\subsection{Direct NAATs for Oral, Dermal, and Conjunctival Swabs}

Swabs have become a mainstay in testing for viral pathogens. Molecular systems that identify respiratory tract infections in nasal swabs [13] or STIs (sexually transmitted infections) in dermal, genital, and conjunctival swabs [173] are used for rapid, accurate patient diagnosis. DNA collection from swabs is attractive because it is simple, minimally invasive, and even enables self-sampling. However, swab-collected specimens are likely to contain polymerase inhibitors such as secreted minerals, electrolytes, hormones, enzymes, immunoglobulins, and cytokines, as well as topical medications [137,174-177]. As a result, many swab tests now on the market remove these inhibitors via extraction methods that are too involved and complex to be suitable for the POC [178].

All of the swab sample studies we examined employed at least one patient sample, and most achieved high sensitivity at a reasonable level of dilution in the buffer used for DNA elution from the solid swab (Figure 7). One remarkable study examined 4518 patient swabs in direct PCR for STR (short tandem repeat) analysis [179]—unfortunately, the authors did not report the yields of DNA obtained or the lowest amounts detected. This is a particularly common problem amongst these references-when the LODs are not reported, it is especially difficult to replicate these procedures or compare the manipulations used in sample storage, DNA replication, and detection [180,181]. Special attention should therefore be paid to reproducibility in future efforts at direct amplification of swab samples. 


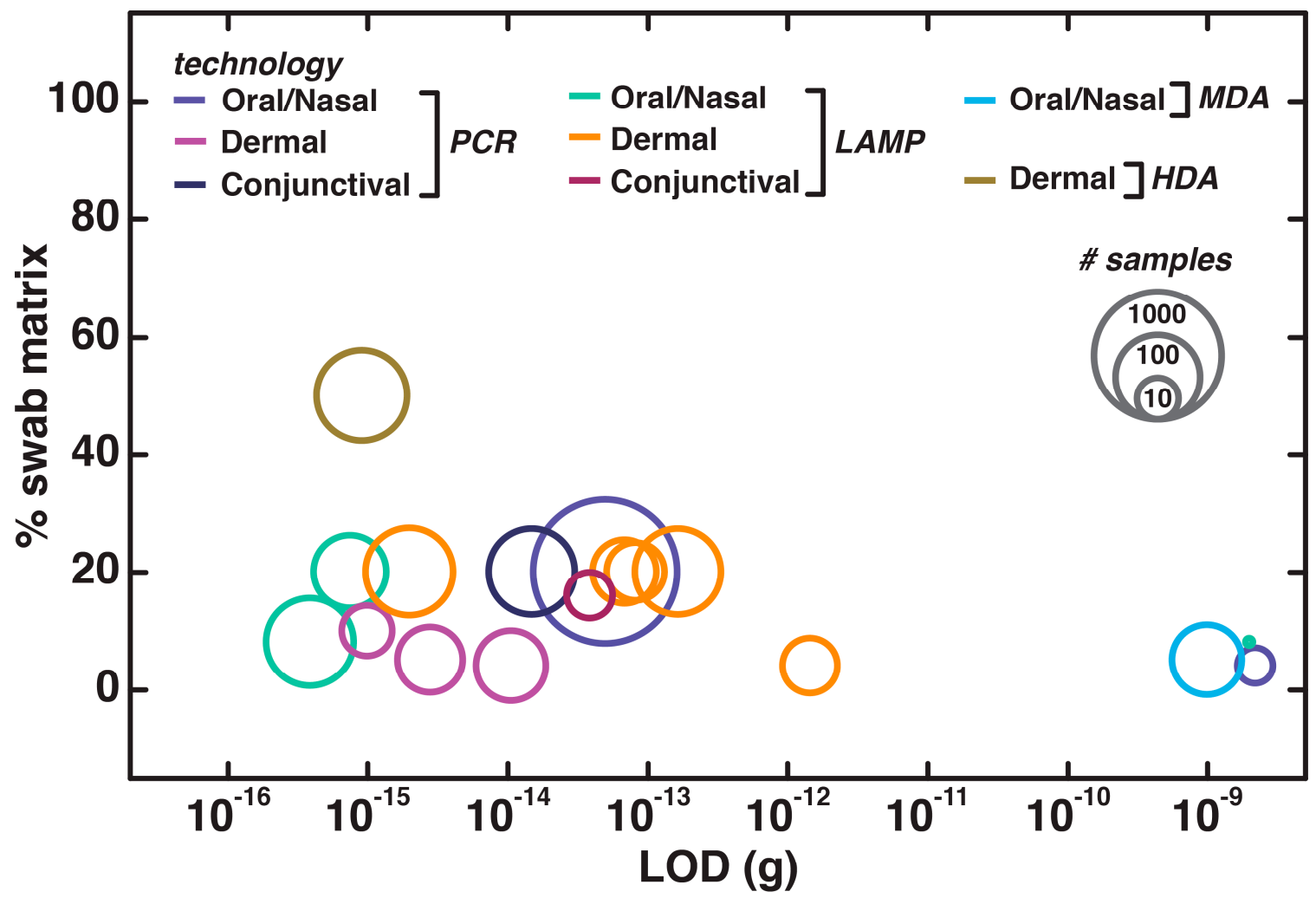

Figure 7. Swab-based procedures for nucleic acid testing, with data presented as in Figure 3.

Typically, elution either at room temperature [51,176,182-186] or with heating [43,44,187-191] is sufficient to generate PCR-amplifiable template from swabs in solution. These methods of dilution or heating can save over thirty minutes of processing time, as with Nihonyanagi et al.'s heating protocol to release MRSA in CellEaseII (Biocosm Inc., Hyogo, Japan) diluents [169]. LAMP-based testing of swab samples can also be performed at room-temperature [192-196] or while heated [145,197-202], as can MDA [84]. In particular, Mahony et al.'s LAMP-based test for influenza A and B achieved an analytical sensitivity of one genome equivalent, operating via a novel swab preparation procedure of vortexing and heating [198].

Moving towards instrument-free molecular diagnostics systems, a lateral-flow strand-displacement amplification (SDA) [203] assay could directly detect MRSA from nasal swabs with a sensitivity of 600 copies/reaction [204]. Lateral flow eliminates the need for expensive detectors. Rogdriguez et al. went one step further by combining paper-based extraction and in situ amplification with lateral flow to develop an RT-LAMP assay for H1N1 in patient nasopharyngeal specimens. Their sensitivity of 500 copies/reaction was well below the mean viral load for H1N1 patients [205]. Pushing to even lower limits of detection, an HDA-based assay with a vertical-flow DNA strip readout [206] could directly test clinical genital swabs in transport medium for HSV types 1 and 2 [207]. The nucleic acid assays had LODs of 5.5 and 34.1 copies/reaction for HSV-1 and HSV-2, respectively, and were able to detect low-viral loads below the sensitivity of culture tests.

The most sensitive tests on swabs rely on LAMP reactions: for example, fewer than 10 copies/reaction of viral targets were seen after brief heating steps in Hank's buffer (Whittaker Bioproducts, Boston, MA, USA) [197], M-Swab diluent (Copan Diagnostics Inc., Murrieta, CA, USA) [198], or water [202]. It is noteworthy is that entire swab samples can be used in amplification reactions, eliminating the loss of starting material that accompanies liquid and hardware transfers. This approach has also been successful in several instances of STR testing $[43,179]$. Rodriguez et al. used a similar approach in detecting clinical levels of H1N1 by passing an in-house elution buffer with the sample of interest through a filter paper-based setup, then amplifying on the filter membrane [205]. 
Future developments could focus on direct reactions with swabs that integrate extraction, amplification, and detection in a single tube for POC usage. This would give low-resource settings alternatives to instrument-dependent assays like the Alere i platform for detecting influenza A \& B from nasal swabs.

\subsection{Direct NAATs for Urine and Stool}

Diseases of the kidney or genitourinary tract can often be detected from stool or urine. Urea destabilizes interactions between primers, template and polymerase, and since urea is typically present in adult urine at concentrations six-fold greater than can be tolerated in PCR reactions, ultracentrifugation, or related procedures are typically used to prepare such samples for nucleic acid testing [208-210]. Molecular tests for the identification of pathogens in stool rely on extraction methods to remove the proteinases, bile salts, polyphenols, and acids that directly inhibit the activity of DNA polymerases [211,212]. Methods for testing external specimens have been integrated into diagnostic screens for pathogens such as Chlamydia trachomatis, Neisseria gonorrhoeae, and Clostridium difficile with high sensitivity and specificity [213-217].

In surveying direct nucleic acid testing methods (Figure 8), we noted that the LODs are generally lower for urine-based tests than for feces-based. However, there is one example of direct PCR in stool samples, taking advantage of buffer additives and enhanced Phire polymerase (New England Biolabs, Ipswich, MA, USA), which achieved a LOD of $0.002 \mathrm{pg}$ of bacterial DNA. However, there is a clear need for increased testing with patient samples, as nearly half of the referenced works do not include any clinical validation. This issue is especially notable with fecal testing, where patient testing is only reported in one study.

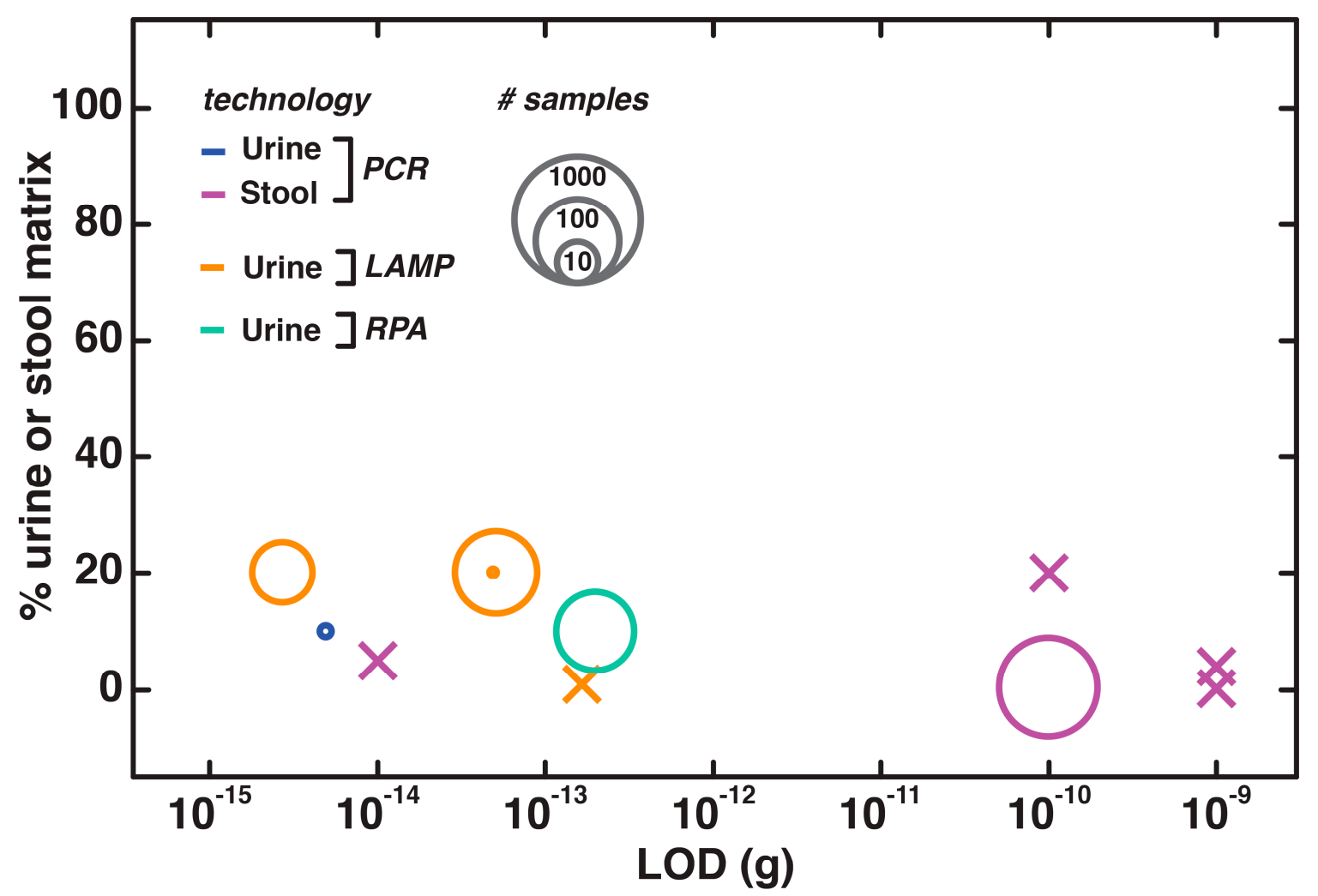

Figure 8. Nucleic acid testing in fecal and urine samples, with data presented as in Figure 3.

Though complex extraction methods are recommended prior to PCR in order to remove inhibitory components of urine and feces, changes to the reaction chemistry could effectively relieve the negative effects of the sample matrix. With urine, this alteration takes the form of a hydrogel-encased reaction [183]. The authors developed a pre-assembled, desiccated, gel-based cassette that is rehydrated 
by the liquid in raw urine samples. The polyacrylamide gel matrix effectively filters biological inhibitors out of the amplification reaction, enabling detection of Mycoplasma homonis and Ureaplasma urealyticum. For feces, the options are to employ inhibitor-resistant polymerases [57] and buffer additives [212]. In the case of one large-scale characterization by Hall et al., the combination of both Phire polymerase (New England Biolabs, Ipswich, MA, USA) and Ampdirect (Biomatrica, San Diego, CA) gave an LOD of nearly one copy/reaction in PCR for Francisella tularensis in $0.5 \%$ stool [56]. One can also lyse bacteria in urine [218] or stool $[219,220]$ through heating to release an amplifiable amount of target DNA with minimal levels of inhibitors. Moore et al. managed to detect Human norovirus repeatedly in 11 out of 12 outbreak stool samples after boiling the diluted feces in PBS [221]. Although centrifugation is employed in some semi-direct methods to create a supernatant from the collected stool, we believe a dilution step could accomplish the same feat by allowing solids to settle at the base of a highly aqueous, non-viscous sample.

Isothermal amplification techniques like LAMP and RPA generally demonstrate a higher tolerance than PCR for urine, as they can be carried out directly. As such, LAMP-based assays without any pre-processing steps or chemical enhancements have detected the causative agents of viral infections [82,127,131] or STIs [222,223], and pathogenic bacteria such as Escherichia coli [224]. The developers of the recently established isothermal method SIBA showed the utility of this amplification technique by detecting Chlamydia trachomatis and Neisseria gonorrhoeae in a low-copy urine sample [25].

\section{Discussion}

The landscape of molecular diagnostics is constantly advancing, as is the current paradigm of healthcare. The advent of mobile health and telemedicine has decentralized patient care. It has also put a new emphasis on usability and non-invasiveness in disease testing. Nucleic acid diagnostics that reduce the difficulties and expenditures of standard multi-step procedures by direct amplification can expedite patient testing in POC, hospital, and laboratory situations [225]. In this review, we are thus motivated to discuss the current state of the art for direct NAATs: assays and platforms that require minimal or no sample preparation procedures. We search the literature from 1989 to 2017 and find 174 published works that we consider direct NAATs. We first categorize these works based on the type of complex samples. We subsequently employ bubble plots to facilitate the comparison of the amplification method, robustness in complex media, sensitivity to target, and clinical usage. Our findings indicate that the majority of direct NAATs exhibit a tolerance of less than $17 \%$ for their sample of interest, and fewer than 30 patient-based evaluations. Still, there are diagnostic procedures that far surpass these averages. Sim et al.'s study of direct PCR on 4518 buccal swabs [179], for instance, is robust and carried out directly on the entire sample for maximal ease. Improvements must continue to be made for all sample types in terms of facilitating this level of evaluation with clinical samples.

Despite significant developments to date, there remain several challenges for realizing direct NAATs with user-friendliness, consistency, and generalizability. In furthering the development of direct testing, it is important to take a holistic approach and consider the type of sample to be analyzed, the method of sample acquisition, the throughput and volume, and any chemical or mechanical requirements, and the amplification technique. Another key point to note is that different matrices will function best in different environments. An improved understanding of the mechanisms behind emerging nucleic acid amplification reactions and mutant polymerases will enable the rationalization of how inhibitory compounds can make or break an amplification system. Furthermore, molecular assays have much to learn from diagnostics that are continuously being developed in the commercial pipeline. Proprietary technology will always hold knowledge at a cost to the user, but the implementation of new ideas can lead researchers towards better and more successful ways in which to modernize the ever-changing field of disease testing. 


\section{Conclusions}

As we enter the age of electronic, mobile, and personalized medicine, there remains much room for creativity and innovation in the design of NAATs and POC diagnostics. Molecular diagnostics, as the highest-growing segment of all in vitro diagnostic products [226], truly have great potential for both developed and low-resource areas. The diagnostic community continues to strive for tests that are reliable against variable electrical resources, water quality, trained staff, or harsh environmental conditions [227,228]. Researchers continue to seek approvals such as the FDA's CLIA waivers or the WHO's ASSURED (affordable, sensitive, specific, user-friendly, rapid and robust, equipment-free, and delivered to end-users) criteria. In this regard, direct NAATs present a promising approach. Through this review, it is our hope to stimulate the discussion on direct NAATs and their potential as POC diagnostics. Ultimately, we seek to help accelerate the development of POC diagnostics that can be CLIA waived and/or meet the WHO ASSURED criteria, thereby ushering in the next revolution in healthcare.

Supplementary Materials: The following are available online at http://www.mdpi.com/2079-6374/9/4/117/s1, Table S1: Detailed Properties of Amplification Assays.

Author Contributions: Conceptualization, F.M.W.; methodology, F.M.W.; validation, F.M.W. and K.H.; formal analysis, F.M.W.; investigation, F.M.W.; resources, F.M.W.; data curation, F.M.W.; writing-original draft preparation, F.M.W.; writing-review and editing, F.M.W. and K.H.; visualization, F.M.W.

Funding: This research received no external funding.

Acknowledgments: The authors acknowledge the support of H.T. Soh in the initial stages of manuscript preparation.

Conflicts of Interest: The authors declare no conflict of interest.

\section{References}

1. Gaydos, C.; Hardick, J. Point of care diagnostics for sexually transmitted infections: Perspectives and advances. Expert Rev. Anti. Infect. Ther. 2014, 12, 657-672. [CrossRef]

2. Wang, S.; Xu, F.; Demirci, U. Advances in developing HIV-1 viral load assays for resource-limited settings. Biotechnol. Adv. 2010, 28, 770-781. [CrossRef] [PubMed]

3. Chin, C.D.; Linder, V.; Sia, S.K. Commercialization of microfluidic point-of-care diagnostic devices. Lab Chip 2012, 12, 2118-2134. [CrossRef] [PubMed]

4. Kovarik, M.L.; Gach, P.C.; Ornoff, D.M.; Wang, Y.; Balowski, J.; Farrag, L.; Allbritton, N.L. Micro total analysis systems for cell biology and biochemical assays. Anal. Chem. 2012, 84, 516-540. [CrossRef]

5. Zhang, Y.; Ozdemir, P. Microfluidic DNA amplification-A review. Anal. Chim. Acta 2009, 638, 115-125. [CrossRef] [PubMed]

6. Gill, P.; Ghaemi, A. Nucleic acid isothermal amplification technologies: A review. Nucleosides Nucleotides Nucleic Acids 2008, 27, 224-243. [CrossRef] [PubMed]

7. Niemz, A.; Ferguson, T.M.; Boyle, D.S. Point-of-care nucleic acid testing for infectious diseases. Trends Biotechnol. 2011, 29, 240-250. [CrossRef] [PubMed]

8. Craw, P.; Balachandran, W. Isothermal nucleic acid amplification technologies for point-of-care diagnostics: A critical review. Lab Chip 2012, 12, 2469-2486. [CrossRef]

9. Dineva, M.A.; Mahilum-Tapay, L.; Lee, H. Sample preparation: A challenge in the development of point-of-care nucleic acid-based assays for resource-limited settings. Analyst 2007, 132, 1193-1199. [CrossRef]

10. Schnepf, N.; Scieux, C.; Resche-Riggon, M.; Feghoul, L.; Xhaard, A.; Gallien, S.; Molina, J.M.; Socié, G.; Viglietti, D.; Simon, F.; et al. Fully automated quantification of cytomegalovirus (CMV) in whole blood with the new sensitive Abbott realTime CMV assay in the era of the CMV international standard. J. Clin. Microbiol. 2013, 51, 2096-2102. [CrossRef]

11. Haliski, J. FDA Grants First CLIA Waiver for Nucleic Acid-Based Flu Diagnostic Test; Food and Drug Administration: Silver Spring, MD, USA, 2015.

12. Bost, W. Focus Diagnostics Receives FDA Clearance for Moderate Complexity Simplexa HSV 1 \& 2 Direct Molecular Test for Aiding the Diagnosis of Encephalitis; Quest Diagnostics: Madison, NJ, USA, 2014. 
13. Chapin, K.C.; Flores-Cortez, E.J. Performance of the Molecular Alere i Influenza A\&B Test Compared to That of the Xpert Flu A/B Assay. J. Clin. Microbiol. 2015, 53, 706-709. [PubMed]

14. Hazelton, B.; Gray, T.; Ho, J.; Ratnamohan, V.M.; Dwyer, D.E.; Kok, J. Detection of influenza A and B with the Alere ${ }^{\mathrm{TM}}$ i Influenza A\&B: A novel isothermal nucleic acid amplification assay. Influenza Other Respi. Viruses 2015, 9, 151-154.

15. Bell, J.J.; Selvarangan, R. Evaluation of the Alere i Influenza A\&B Nucleic Acid Amplification Test by Use of Respiratory Specimens Collected in Viral Transport Medium. J. Clin. Microbiol. 2014, 52, 3992-3995. [PubMed]

16. Nie, S.; Roth, R.B.; Stiles, J.; Mikhlina, A.; Lu, X.; Tang, Y.-W.; Babady, N.E. Evaluation of Alere i Influenza A\&B for Rapid Detection of Influenza Viruses A and B. J. Clin. Microbiol. 2014, 52, 3339-3344. [PubMed]

17. Notomi, T.; Okayama, H.; Masubuchi, H.; Yonekawa, T.; Watanabe, K.; Amino, N.; Hase, T. Loop-mediated isothermal amplification of DNA. Nucleic Acids Res. 2000, 28, E63. [CrossRef] [PubMed]

18. Nagamine, K.; Hase, T.; Notomi, T. Accelerated reaction by loop-mediated isothermal amplification using loop primers. Mol. Cell. Probes 2002, 16, 223-229. [CrossRef] [PubMed]

19. Thai, H.T.C.; Le, M.Q.; Vuong, C.D.; Parida, M.; Minekawa, H.; Notomi, T.; Hasebe, F.; Morita, K. Development and evaluation of a novel loop-mediated isothermal amplification method for rapid detection of severe acute respiratory syndrome coronavirus. J. Clin. Microbiol. 2004, 42, 1956-1961. [CrossRef] [PubMed]

20. Compton, J. Nucleic Acid Sequence-Based Amplification. Nature 1991, 350, 91-92. [CrossRef]

21. Pardee, K.; Green, A.A.; Takahashi, M.K.; Braff, D.; Lambert, G.; Lee, J.W.; Ferrante, T.; Ma, D.; Donghia, N.; Fan, M.; et al. Rapid, Low-Cost Detection of Zika Virus Using Programmable Biomolecular Components. Cell 2016, 165, 1255-1266. [CrossRef] [PubMed]

22. Verkooyen, R.P.; Noordhoek, G.T.; Klapper, P.E.; Schirm, J.; Cleator, G.M.; Ieven, M.; Hoddevik, G.; Reid, J. Reliability of Nucleic Acid Amplification Methods for Detection of Chlamydia trachomatis in Urine: Results of the First International Collaborative Quality Control Study among 96 Laboratories Reliability of Nucleic Acid Amplification Methods for Detectio. J. Clin. Microbiol. 2003, 41, 3013-3016. [CrossRef]

23. Piepenburg, O.; Williams, C.H.; Stemple, D.L.; Armes, N.A. DNA detection using recombination proteins. PLoS Biol. 2006, 4, e204. [CrossRef] [PubMed]

24. Hoser, M.J.; Mansukoski, H.K.; Morrical, S.W.; Eboigbodin, K.E. Strand Invasion Based Amplification (SIBA): A novel isothermal DNA amplification technology demonstrating high specificity and sensitivity for a single molecule of target analyte. PLoS ONE 2014, 9, e112656. [CrossRef] [PubMed]

25. Eboigbodin, K.E.; Hoser, M.J. Multiplex Strand Invasion Based Amplification (mSIBA) assay for detection of Chlamydia trachomatis and Neisseria gonorrhoeae. Sci. Rep. 2016, 6, 20487. [CrossRef] [PubMed]

26. Dean, F.B.; Hosono, S.; Fang, L.; Wu, X.; Faruqi, A.F.; Bray-Ward, P.; Sun, Z.; Zong, Q.; Du, Y.; Du, J.; et al. Comprehensive human genome amplification using multiple displacement amplification. Proc. Natl. Acad. Sci. USA 2002, 99, 5261-5266. [CrossRef] [PubMed]

27. Dirks, R.M.; Pierce, N. a Triggered amplification by hybridization chain reaction. Proc. Natl. Acad. Sci. USA 2004, 101, 15275-15278. [CrossRef] [PubMed]

28. Wang, X.; Ge, L.; Yu, Y.; Dong, S.; Li, F. Highly sensitive electrogenerated chemiluminescence biosensor based on hybridization chain reaction and amplification of gold nanoparticles for DNA detection. Sens. Actuators B Chem. 2015, 220, 942-948. [CrossRef]

29. Mullis, K.; Faloona, F.; Scharf, S. Specific enzymatic amplification of DNA in vitro: The polymerase chain reaction. Cold Spring Harb. 1986, 51, 263-273. [CrossRef] [PubMed]

30. Pavšič, J.; Devonshire, A.S.; Parkes, H.; Schimmel, H.; Foy, C.A.; Karczmarczyk, M.; Gutiérrez-Aguirre, I.; Honeyborne, I.; Huggett, J.F.; McHugh, T.D.; et al. Standardization of nucleic acid tests for clinical measurements of bacteria and viruses. J. Clin. Microbiol. 2015, 53, 2008-2014. [CrossRef]

31. Banada, P.P.; Chakravorty, S.; Shah, D.; Burday, M.; Mazzella, F.M.; Alland, D. Highly sensitive detection of staphylococcus aureus directly from patient blood. PLoS ONE 2012, 7, e31126. [CrossRef]

32. De Franchis, R.; Cross, N.C.P.; Foulkes, N.S.; Cox, T.M. A potent inhibitor of Taq polymerase copurifies with human genomic DNA. Nucleic Acids Res. 1988, 16, 10355. [CrossRef]

33. Akane, A.; Matsubara, K.; Nakamura, H.; Takahashi, S.; Kimura, K. Identification of the Heme Compound Copurified with Deoxyribonucleic Acid (DNA) from Bloodstains, a Major Inhibitor of Polymerase Chain Reaction (PCR) Amplification. J. Forensic Sci. 1994, 39, 362-372. [CrossRef] [PubMed] 
34. Rossen, L.; Norskov, P.; Hoimstrom, K.; Rasmussen, O.F. Inhibition of PCR by components of food samples, microbial diagnostic assays and DNA-extraction solutions. Int. J. Food Microbiol. 1992, 17, 37-45. [CrossRef]

35. Al-soud, W.A.; Rådström, P. Purification and Characterization of PCR-Inhibitory Components in Blood Cells. J. Clin. Microbiol. 2001, 39, 485-493. [CrossRef] [PubMed]

36. Burckhardt, J. Amplification of DNA from whole blood. PCR Methods Appl. 1994, 3, 239-243. [CrossRef] [PubMed]

37. Morton, B.A.; Diniz, P.P.V.D.P. Detection of Bartonella quintana DNA in the presence of human and feline whole blood by single-tube PCR without DNA extraction. Microbiol. Discov. 2013, 1, 7. [CrossRef]

38. Nishimura, N.; Nakayama, T.; Tonoike, H.; Kojima, K.; Kato, S. Direct polymerase chain reaction from whole blood without DNA isolation. Ann. Clin. Biochem. 2000, 37, 674-680. [CrossRef]

39. Yang, Y.G.; Kim, J.Y.; Song, Y.H.; Kim, D.S. A novel buffer system, AnyDirect, can improve polymerase chain reaction from whole blood without DNA isolation. Clin. Chim. Acta 2007, 380, 112-117. [CrossRef]

40. Walker, F.M.; Ahmad, K.M.; Eisenstein, M.; Soh, H.T. Transformation of Personal Computers and Mobile Phones into Genetic Diagnostic Systems. Anal. Chem. 2014, 86, 9236-9241. [CrossRef]

41. Castley, A.; Higgins, M.; Ivey, J.; Mamotte, C.; Sayer, D.C.; Christiansen, F.T. Clinical applications of whole-blood PCR with real-time instrumentation. Clin. Chem. 2005, 51, 2025-2030. [CrossRef]

42. Chomczynski, P.; Rymaszewski, M. Alkaline polyethylene glycol-based method for direct PCR from bacteria, eukaryotic tissue samples, and whole blood. Biotechniques 2004, 40, 454-458. [CrossRef]

43. Klintschar, M.; Neuhuber, F. Evaluation of an alkaline lysis method for the extraction of DNA from whole blood and forensic stains for STR analysis. J. Forensic Sci. 2000, 45, 669-673. [CrossRef] [PubMed]

44. Rudbeck, L.; Dissing, J. Rapid, simple alkaline extraction of human genomic DNA from whole blood, buccal epithelial cells, semen and forensic stains for PCR. Biotechniques 1998, 25, 588-592. [CrossRef] [PubMed]

45. Manage, D.P.; Lauzon, J.; Atrazhev, A.; Pang, X.; Pilarski, L.M. A novel method for sample delivery and testing of whole blood: Gel strip PCR for point of care (POC) molecular diagnostics. Lab Chip 2013, 13, 4011-4014. [CrossRef] [PubMed]

46. Sharma, R.; Virdi, A.S.; Singh, P. A novel method for whole blood PCR without pretreatment. Gene 2012, 501, 85-88. [CrossRef] [PubMed]

47. Taylor, B.J.; Martin, K.A.; Arango, E.; Agudelo, O.M.; Maestre, A.; Yanow, S.K. Real-time PCR detection of Plasmodium directly from whole blood and filter paper samples. Malar. J. 2011, 10, 244. [CrossRef] [PubMed]

48. Howard, R.; Leathart, J.B.S.; French, D.J.; Krishan, E.; Kohnke, H.; Wadelius, M.; Van Schie, R.; Verhoef, T.; Maitland-van der Zee, A.H.; Daly, A.K.; et al. Genotyping for CYP2C9 and VKORC1 alleles by a novel point of care assay with HyBeacon ${ }^{\circledR}$ probes. Clin. Chim. Acta 2011, 412, 2063-2069. [CrossRef]

49. Zhang, Z.; Kermekchiev, M.B.; Barnes, W.M. Direct DNA Amplification from Crude Clinical Samples Using a PCR Enhancer Cocktail and Novel Mutants of Taq. J. Mol. Diagn. 2010, 12, 152-161. [CrossRef] [PubMed]

50. Kermekchiev, M.B.; Kirilova, L.I.; Vail, E.E.; Barnes, W.M. Mutants of Taq DNA polymerase resistant to PCR inhibitors allow DNA amplification from whole blood and crude soil samples. Nucleic Acids Res. 2009, 37, e40. [CrossRef] [PubMed]

51. Park, S.J.; Kim, J.Y.; Yang, Y.G.; Lee, S.H. Direct STR amplification from whole blood and blood- or saliva-spotted FTA without DNA purification. J. Forensic Sci. 2008, 53, 335-341. [CrossRef]

52. Bu, Y.; Huang, H.; Zhou, G. Direct polymerase chain reaction (PCR) from human whole blood and filter-paper-dried blood by using a PCR buffer with a higher pH. Anal. Biochem. 2008, 375, 370-372. [CrossRef]

53. Silvy, M.; Bres, J.C.; Grimaldi, A.; Movia, C.; Muriel, V.; Roubinet, F.; Chiaroni, J.; Bailly, P. A simple genotyping procedure without DNA extraction to identify rare blood donors. Vox Sang. 2015, 109, 173-180. [CrossRef] [PubMed]

54. Liu, E.-P.; Wang, Y.; He, X.-H.; Guan, J.-J.; Wang, J.; Qin, Z.-H.; Sun, W.-P. Whole Blood PCR Amplification with Pfu DNA Polymerase and Its Application in Single-Nucleotide Polymorphism Analysis. Genet. Test. Mol. Biomark. 2015, 19, 610-616. [CrossRef] [PubMed]

55. Minogue, T.D.; Rachwal, P.A.; Trombley Hall, A.; Koehler, J.W.; Weller, S.A. Cross-institute evaluations of inhibitor-resistant PCR reagents for direct testing of aerosol and blood samples containing biological warfare agent DNA. Appl. Environ. Microbiol. 2014, 80, 1322-1329. [CrossRef] [PubMed]

56. Hall, A.T.; Zovanyi, A.M.; Christensen, D.R.; Koehler, J.W.; Minogue, T.D. Evaluation of inhibitor-resistant real-time PCR methods for diagnostics in clinical and environmental samples. PLoS ONE 2013, 8, e73845. 
57. Al-soud, W.A.; Rådström, P. Capacity of Nine Thermostable DNA Polymerases To Mediate DNA Amplification in the Presence of PCR-Inhibiting Samples. Appl. Environ. Microbiol. 1998, 64, 3748-3753. [PubMed]

58. Panaccio, M.; Lew, A. PCR based diagnosis in the presence of $8 \%$ (v/v) blood. Nucleic Acids Res. 1991, 19, 1151. [CrossRef]

59. Port, J.R.; Nguetse, C.; Adukpo, S.; Velavan, T.P. A reliable and rapid method for molecular detection of malarial parasites using microwave irradiation and loop mediated isothermal amplification. Malar. J. 2014, 13, 454. [CrossRef] [PubMed]

60. Meganathan, P.; Singh, S.; Ling, L.Y.; Singh, J.; Subrayan, V.; Nissapatorn, V. Detection of Toxoplasma gondii DNA by PCR following microwave treatment of serum and whole blood. Southeast Asian J. Trop. Med. Public Health 2010, 41, 265-273.

61. El-Awady, M.K.; El-Hosseiny, L.A.; Ismail, S.M.; Abdel-Aziz, M.T.; El-Demellawy, M.A. Comparison between Toxoplasma gondii DNA and specific immunoglobulins during pregnancy. La Rev. Sante la Mediterr. Orient. 2000, 6, 888-897.

62. Jadaon, M.M.; Dashti, A.A.; Lewis, H.L.; Habeeb, F.M. Whole-blood polymerase chain reaction and restriction fragment length polymorphism: A simplified method by microwave irradiation. Med. Princ. Pract. 2009, 18, 280-283. [CrossRef]

63. McCusker, J.; Dawson, M.T.; Noone, D.; Gannon, F.; Smith, T. Improved method for direct PCR amplification from whole blood. Nucleic Acids Res. 1992, 20, 6747. [CrossRef] [PubMed]

64. Mercier, B.; Gaucher, C.; Feugeas, O.; Mazurier, C. Direct PCR from whole blood, without DNA extraction. Nucleic Acids Res. 1990, 18, 5908. [CrossRef] [PubMed]

65. Modak, S.S.; Barber, C.A.; Geva, E.; Abrams, W.R.; Malamud, D.; Ongagna, Y.S.Y. Rapid Point-of-Care Isothermal Amplification Assay for the Detection of Malaria without Nucleic Acid Purification. Infect. Dis. 2016, 9, 1-9. [CrossRef]

66. Paris, D.H.; Blacksell, S.D.; Newton, P.N.; Day, N.P.J. Simple, rapid and sensitive detection of Orientia tsutsugamushi by loop-isothermal DNA amplification. Trans. R. Soc. Trop. Med. Hyg. 2008, 102, 1239-1246. [CrossRef]

67. Njiru, Z.K.; Mikosza, A.S.J.; Matovu, E.; Enyaru, J.C.K.; Ouma, J.O.; Kibona, S.N.; Thompson, R.C.A.; Ndung'u, J.M. African trypanosomiasis: Sensitive and rapid detection of the sub-genus Trypanozoon by loop-mediated isothermal amplification (LAMP) of parasite DNA. Int. J. Parasitol. 2008, 38, 589-599. [CrossRef] [PubMed]

68. Poon, L.L.M.; Wong, B.W.Y.; Ma, E.H.T.; Chan, K.H.; Chow, L.M.C.; Abeyewickreme, W.; Tangpukdee, N.; Yuen, K.Y.; Guan, Y.; Looareesuwan, S.; et al. Sensitive and inexpensive molecular test for falciparum malaria: Detecting Plasmodium falciparum DNA directly from heat-treated blood by loop-mediated isothermal amplification. Clin. Chem. 2006, 52, 300-303. [CrossRef]

69. Britton, S.; Cheng, Q.; Sutherland, C.J.; McCarthy, J.S. A simple, high-throughput, colourimetric, field applicable loop-mediated isothermal amplification (HtLAMP) assay for malaria elimination. Malar. J. 2015, 14, 335. [CrossRef]

70. Hopkins, H.; González, I.J.; Polley, S.D.; Angutoko, P.; Ategeka, J.; Asiimwe, C.; Agaba, B.; Kyabayinze, D.J.; Sutherland, C.J.; Perkins, M.D.; et al. Highly sensitive detection of malaria parasitemia in a malaria-endemic setting: Performance of a new loop-mediated isothermal amplification kit in a remote clinic in Uganda. J. Infect. Dis. 2013, 208, 645-652. [CrossRef]

71. Polley, S.D.; González, I.J.; Mohamed, D.; Daly, R.; Bowers, K.; Watson, J.; Mewse, E.; Armstrong, M.; Gray, C.; Perkins, M.D.; et al. Clinical evaluation of a loop-mediated amplification kit for diagnosis of imported malaria. J. Infect. Dis. 2013, 208, 637-644. [CrossRef]

72. Sirichaisinthop, J.; Buates, S.; Watanabe, R.; Han, E.T.; Suktawonjaroenpon, W.; Krasaesub, S.; Takeo, S.; Tsuboi, T.; Sattabongkot, J. Short report: Evaluation of loop-mediated isothermal amplification (LAMP) for malaria diagnosis in a field setting. Am. J. Trop. Med. Hyg. 2011, 85, 594-596. [CrossRef]

73. Soejima, M.; Egashira, K.; Kawano, H.; Kawaguchi, A.; Sagawa, K.; Koda, Y. Rapid detection of haptoglobin gene deletion in alkaline-denatured blood by loop-mediated isothermal amplification reaction. J. Mol. Diagn. 2011, 13, 334-339. [CrossRef] [PubMed]

74. Polley, S.D.; Mori, Y.; Watson, J.; Perkins, M.D.; González, I.J.; Notomi, T.; Chiodini, P.L.; Sutherland, C.J. Mitochondrial DNA targets increase sensitivity of malaria detection using loop-mediated isothermal amplification. J. Clin. Microbiol. 2010, 48, 2866-2871. [CrossRef] [PubMed] 
75. Chen, J.H.; Lu, F.; Lim, C.S.; Kim, J.Y.; Ahn, H.J.; Suh, I.B.; Takeo, S.; Tsuboi, T.; Sattabongkot, J.; Han, E.T. Detection of Plasmodium vivax infection in the Republic of Korea by loop-mediated isothermal amplification (LAMP). Acta Trop. 2010, 113, 61-65. [CrossRef] [PubMed]

76. Suzuki, R.; Ihira, M.; Enomoto, Y.; Yano, H.; Maruyama, F.; Emi, N.; Asano, Y.; Yoshikawa, T. Heat denaturation increases the sensitivity of the cytomegalovirus loop-mediated isothermal amplification method. Microbiol. Immunol. 2010, 54, 466-470. [CrossRef] [PubMed]

77. Benzine, J.W.; Brown, K.M.; Agans, K.N.; Godiska, R.; Mire, C.E.; Gowda, K.; Converse, B.; Geisbert, T.W.; Mead, D.A.; Chander, Y. Molecular Diagnostic Field Test for Point-of-Care Detection of Ebola Virus Directly from Blood. J. Infect. Dis. 2016, 214, S234-S242. [CrossRef] [PubMed]

78. Damhorst, G.L.; Duarte-Guevara, C.; Chen, W.; Ghonge, T.; Cunningham, B.T.; Bashir, R. Smartphone-Imaged HIV-1 Reverse-Transcription Loop-Mediated Isothermal Amplification (RT-LAMP) on a Chip from Whole Blood. Engineering 2015, 1, 324-335. [CrossRef] [PubMed]

79. Hayashida, K.; Kajino, K.; Hachaambwa, L.; Namangala, B.; Sugimoto, C. Direct Blood Dry LAMP: A Rapid, Stable, and Easy Diagnostic Tool for Human African Trypanosomiasis. PLoS Negl. Trop. Dis. 2015, 9, e0003578. [CrossRef] [PubMed]

80. Ebbinghaus, P.; von Samson-Himmelstjerna, G.; Krücken, J. Direct loop-mediated isothermal amplification from Plasmodium chabaudi infected blood samples: Inability to discriminate genomic and cDNA sequences. Exp. Parasitol. 2012, 131, 40-44. [CrossRef] [PubMed]

81. Curtis, K.A.; Rudolph, D.L.; Owen, S.M. Sequence-specific detection method for reverse transcription, loop-mediated isothermal amplification of HIV-1. J. Med. Virol. 2009, 81, 966-972. [CrossRef]

82. Priye, A.; Bird, S.W.; Light, Y.K.; Ball, C.S.; Negrete, O.A.; Meagher, R.J. A smartphone-based diagnostic platform for rapid detection of Zika, chikungunya, and dengue viruses. Sci. Rep. 2017, 7, 44778. [CrossRef] [PubMed]

83. Ball, C.S.; Light, Y.K.; Koh, C.Y.; Wheeler, S.S.; Coffey, L.L.; Meagher, R.J. Quenching of Unincorporated Amplification Signal Reporters in Reverse-Transcription Loop-Mediated Isothermal Amplification Enabling Bright, Single-Step, Closed-Tube, and Multiplexed Detection of RNA Viruses. Anal. Chem. 2016, 88, 3562-3568. [CrossRef] [PubMed]

84. Hosono, S.; Faruqi, A.F.; Dean, F.B.; Du, Y.; Sun, Z.; Wu, X.; Du, J.; Kingsmore, S.F.; Egholm, M.; Lasken, R.S. Unbiased whole-genome amplification directly from clinical samples. Genome Res. 2003, 13, 954-964. [CrossRef] [PubMed]

85. Johannessen, A. Dried blood spots in HIV monitoring: Applications in resource-limited settings. Bioanalysis 2010, 2, 1893-1908. [CrossRef] [PubMed]

86. Zhang, Q.; Wang, L.; Jiang, Y.; Fang, L.; Pan, P.; Gong, S.; Yao, J.; Tang, Y.W.; Vermund, S.H.; Jia, Y. Early infant human immunodeficiency virus type 1 detection suitable for resource-limited settings with multiple circulating subtypes by use of nested three-monoplex DNA PCR and dried blood spots. J. Clin. Microbiol. 2008, 46, 721-726. [CrossRef] [PubMed]

87. Smit, P.W.; Elliott, I.; Peeling, R.W.; Mabey, D.; Newton, P.N. Review article: An overview of the clinical use of filter paper in the diagnosis of tropical diseases. Am. J. Trop. Med. Hyg. 2014, 90, 195-210. [CrossRef] [PubMed]

88. Chediak, A. The diagnosis of syphilis on a dessicated and defibrinated blood drop. Rev. Med. Cubana 1932, 953-956.

89. Guthrie, R.; Susi, A. A simple phenylalanine method for detecting phenylketonuria in large populations of newborn infants. Pediatrics 1963, 32, 338-343.

90. Bertagnolio, S.; Parkin, N.T.; Jordan, M.; Brooks, J.; G, G.-L.J. Dried blood spots for HIV-1 drug resistance and viral load testing: A review of current knowledge and WHO efforts for global HIV drug resistance surveillance. AIDS Rev. 2010, 12, 195-208.

91. Solomon, A.W.; Engels, D.; Bailey, R.L.; Blake, I.M.; Brooker, S.; Chen, J.X.; Chen, J.H.; Churcher, T.S.; Drakeley, C.J.; Edwards, T.; et al. A diagnostics platform for the integrated mapping, monitoring, and surveillance of neglected tropical diseases: Rationale and target product profiles. PLoS Negl. Trop. Dis. 2012, 6, e1746. [CrossRef]

92. Raskin, S.; Iii, J.A.P.; Kaplan, G.; Mcclure, M.; Vnencak-Jones, C. Cystic Fibrosis Genotyping by Direct PCR Analysis of Guthrle Blood Spots. Genome Res. 1992, 2, 154-156. [CrossRef] 
93. Hall, D.E.; Roy, R. An evaluation of direct PCR amplification. Croat. Med. J. 2014, 55, 655-661. [CrossRef] [PubMed]

94. Makowski, G.S.; Davis, E.L.; Aslanzadeh, J.; Hopfer, S.M. Enhanced direct amplification of Guthrie card DNA following selective elution of PCR inhibitors. Nucleic Acids Res. 1995, 23, 3788-3789. [CrossRef] [PubMed]

95. Raskin, S.; Phillips, J.A.; Krishnamani, M.R.; Vnencak-Jones, C.; Parker, R.A.; Rozov, T.; Cardieri, J.M.; Marostica, P.; Abreu, F.; Giugliani, R. DNA analysis of cystic fibrosis in Brazil by direct PCR amplification from Guthrie cards. Am. J. Med. Genet. 1993, 46, 665-669. [CrossRef] [PubMed]

96. Seltzer, W.K.; Accurso, F.; Fall, M.Z.; VanRiper, A.J.; Descartes, M.; Huang, Y.; McCabe, E.R. Screening for cystic fibrosis: Feasibility of molecular genetic analysis of dried blood specimens. Biochem. Med. Metab. Biol. 1991, 46, 105-109. [CrossRef]

97. Schwartz, E.I.; Khalchitsky, S.E.; Eisensmith, R.C.; Woo, S.L.C. Polymerase chain reaction amplification from dried blood spots on Guthrie cards. Lancet 1990, 336, 639-640. [CrossRef]

98. Caggana, M.; Conroy, J.M.; Pass, K.A. Rapid, efficient method for multiplex amplification from filter paper. Hum. Mutat. 1998, 11, 404-409. [CrossRef]

99. Nelson, P.V.; Carey, W.F.; Morris, C.P. Gene amplification directly from Guthrie blood spots. Lancet 1990, 336, 1451-1452. [CrossRef]

100. Jinks, D.C.; Minter, M.; Tarver, D.A.; Vanderford, M.; Hejtmancik, J.F.; McCabe, E.R. Molecular genetic diagnosis of sickle cell disease using dried blood specimens on blotters used for newborn screening. Hum. Genet. 1989, 81, 363-366. [CrossRef]

101. Mackey, K.; Steinkamp, A.; Chomczynski, P. DNA Extraction from Small Blood Volumes and the Processing of Cellulose Blood Cards for Use in Polymerase Chain Reaction. Mol. Biotechnol. 1998, 9, 1-5. [CrossRef]

102. Ramos-Díaz, R.; Gutiérrez-Nicolás, F.; Nazco-Casariego, G.J.; González-Perera, I.; Pérez-Pérez, J.A. Validation of a fast and low-cost alkaline lysis method for gDNA extraction in a pharmacogenetic context. Cancer Chemother. Pharmacol. 2015, 75, 1095-1098. [CrossRef]

103. Song, Y.; Fahs, A.; Feldman, C.; Shah, S.; Gu, Y.; Wang, Y.; Machado, R.F.; Wunderink, R.G.; Chen, J. A reliable and effective method of DNA isolation from old human blood paper cards. Springerplus 2013, 2, 616. [CrossRef] [PubMed]

104. Miura, M.; Tanigawa, C.; Fujii, Y.; Kaneko, S. Comparison of six commercially-available DNA polymerases for direct PCR. Rev. Inst. Med. Trop. Sao Paulo 2013, 55, 401-406. [CrossRef] [PubMed]

105. Bereczky, S.; Mårtensson, A.; Gil, J.P.; Farnert, A. Short Report: Rapid DNA Extraction from Archive Blood Spots on Filter Paper for Genotyping of Plasmodium Falciparum. Am. J. Trop. Med. Hyg. 2005, 72, $249-251$. [CrossRef] [PubMed]

106. Kline, M.C.; Duewer, D.L.; Redman, J.W.; Butler, J.M.; Boyer, D.A. Polymerase chain reaction amplification of DNA from aged blood stains: Quantitative evaluation of the "suitability for purpose" of four filter papers as archival media. Anal. Chem. 2002, 74, 1863-1869. [CrossRef] [PubMed]

107. Yang, M.; Hendrie, H.C.; Hall, K.; Oluwole, O.S.A.; Hodes, M.E.; Sabota, A. Improved Procedure for Eluting DNA from Dried Blood Spots. Clin. Chem. 1996, 42, 1115-1116. [PubMed]

108. Tao, Z.; Zhou, H.; Xia, H.; Xu, S.; Zhu, H.; Culleton, R.L.; Han, E.; Lu, F. Adaptation of a visualized loop-mediated isothermal amplification technique for field detection of Plasmodium vivax infection. Parasit. Vectors 2011, 4, 115. [CrossRef] [PubMed]

109. Song, Y.; Huang, Y.Y.; Liu, X.; Zhang, X.; Ferrari, M.; Qin, L. Point-of-care technologies for molecular diagnostics using a drop of blood. Trends Biotechnol. 2014, 32, 132-139. [CrossRef] [PubMed]

110. Maton, A. Human Biology and Health; Prentice Hall Science; Pearson Prentice Hall: Upper Saddle River, NJ, USA, 1993; ISBN 9780139811760.

111. Caliendo, A.M.; Valsamakis, A.; Bremer, J.W.; Ferreira-Gonzalez, A.; Granger, S.; Sabatini, L.; Tsongalis, G.J.; Wang, Y.F.W.; Yen-Lieberman, B.; Young, S.; et al. Multilaboratory evaluation of real-time PCR tests for hepatitis B virus DNA quantification. J. Clin. Microbiol. 2011, 49, 2854-2858. [CrossRef] [PubMed]

112. Schwarzenbach, H.; Hoon, D.S.B.; Pantel, K. Cell-free nucleic acids as biomarkers in cancer patients. Nat. Rev. Cancer 2011, 11, 426-437. [CrossRef]

113. Suzuki, N.; Kamataki, A.; Yamaki, J.; Homma, Y. Characterization of circulating DNA in healthy human plasma. Clin. Chim. Acta 2008, 387, 55-58. [CrossRef]

114. Stroun, M.; Anker, P.; Lyautey, J.; Lederrey, C.; Maurice, P.A. Isolation and Characterization of DNA from the Plasma of Cancer Patients. Eur. J. Cancer Clin. Oncol. 1987, 23, 707-712. [CrossRef] 
115. Songjaroen, T.; Dungchai, W.; Chailapakul, O.; Henry, C.S.; Laiwattanapaisal, W. Blood separation on microfluidic paper-based analytical devices. Lab Chip 2012, 12, 3392-3398. [CrossRef] [PubMed]

116. Kim, J.H.; Woenker, T.; Adamec, J.; Regnier, F.E. Simple, miniaturized blood plasma extraction method. Anal. Chem. 2013, 85, 11501-11508. [CrossRef] [PubMed]

117. Liu, C.; Mauk, M.; Gross, R.; Bushman, F.D.; Edelstein, P.H.; Collman, R.G.; Bau, H.H. Membrane-based, sedimentation-assisted plasma separator for point-of-care applications. Anal. Chem. 2013, 85, 10463-10470. [CrossRef] [PubMed]

118. Kersaudy-Kerhoas, M.; Sollier, E. Micro-scale blood plasma separation: From acoustophoresis to egg-beaters. Lab Chip 2013, 13, 3323-3346. [CrossRef] [PubMed]

119. Liu, S.; Wang, Y.; Ming, J.; Lin, Y.; Cheng, C.; Li, F. Enzyme-free and ultrasensitive electrochemical detection of nucleic acids by target catalyzed hairpin assembly followed with hybridization chain reaction. Biosens. Bioelectron. 2013, 49, 472-477. [CrossRef] [PubMed]

120. Nixon, G.; Garson, J.A.; Grant, P.; Nastouli, E.; Foy, C.A.; Huggett, J.F. Comparative Study of Sensitivity, Linearity, and Resistance to Inhibition of Digital and Nondigital Polymerase Chain Reaction and Loop Mediated Isothermal Amplification Assays for Quantification of Human Cytomegalovirus. Anal. Chem. 2014, 86, 4387-4394. [CrossRef]

121. Zhang, X.; Yang, X.; Zhang, Y.; Liu, X.; Zheng, G.; Yang, Y.; Wang, L.; Du, L.; Wang, C. Direct Serum Assay for Cell-Free Bmi-1 mRNA and Its Potential Diagnostic and Prognostic Value for Colorectal Cancer. Clin. Cancer Res. 2014, 21, 1225-1233. [CrossRef]

122. Asaga, S.; Kuo, C.; Nguyen, T.; Terpenning, M.; Giuliano, A.E.; Hoon, D.S.B. Direct serum assay for microRNA-21 concentrations in early and advanced breast cancer. Clin. Chem. 2011, 57, 84-91. [CrossRef]

123. Zhang, L.; Song, X.; Wang, X.; Xie, Y.; Wang, Z.; Xu, Y.; You, X.; Liang, Z.; Cao, H. Circulating DNA of HOTAIR in serum is a novel biomarker for breast cancer. Breast Cancer Res. Treat. 2015, 152, 199-208. [CrossRef]

124. Jang, J.S.; Lee, K.-J. Simple and rapid identification of low level hepatitis B virus DNA by the nested polymerase chain reaction. Arch. Pharm. Res. 1996, 19, 469-474. [CrossRef]

125. Costa, J.; López-Labrador, F.X.; Sánchez-Tapias, J.M.; Mas, A.; Vilella, A.; Olmedo, E.; Vidal, J.; Jimenez de Anta, M.T.; Rodés, J. Microwave treatment of serum facilitates detection of hepatitis B virus DNA by the polymerase chain reaction. Results of a study in anti-HBe positive chronic hepatitis B. J. Hepatol. 1995, 22, 35-42. [CrossRef]

126. Cheyrou, A.; Guyomarc'h, C.; Jasserand, P.; Blouin, P. Improved detection of HBV DNA by PCR after microwave treatment of serum. Nucleic Acids Res. 1991, 19, 4006. [CrossRef] [PubMed]

127. Kaneko, H.; Kawana, T.; Fukushima, E.; Suzutani, T. Tolerance of loop-mediated isothermal amplification to a culture medium and biological substances. J. Biochem. Biophys. Methods 2007, 70, 499-501. [CrossRef] [PubMed]

128. Yoshikawa, T.; Matsuo, T.; Kawamura, Y.; Ohashi, M.; Yonekawa, T.; Kanda, H.; Notomi, T.; Ihira, M. Direct detection of human herpesvirus $6 \mathrm{~B}$ by the LAMP method using newly developed dry-reagents. J. Virol. Methods 2014, 201, 65-67. [CrossRef] [PubMed]

129. Ihira, M.; Sugiyama, H.; Enomoto, Y.; Higashimoto, Y.; Sugata, K.; Asano, Y.; Yoshikawa, T. Direct detection of human herpesvirus 6 DNA in serum by variant specific loop-mediated isothermal amplification in hematopoietic stem cell transplant recipients. J. Virol. Methods 2010, 167, 103-106. [CrossRef]

130. Curtis, K.A.; Rudolph, D.L.; Owen, S.M. Rapid detection of HIV-1 by reverse-transcription, loop-mediated isothermal amplification (RT-LAMP). J. Virol. Methods 2008, 151, 264-270. [CrossRef]

131. Bista, B.R.; Ishwad, C.; Wadowsky, R.M.; Manna, P.; Randhawa, P.S.; Gupta, G.; Adhikari, M.; Tyagi, R.; Gasper, G.; Vats, A. Development of a loop-mediated isothermal amplification assay for rapid detection of BK Virus. J. Clin. Microbiol. 2007, 45, 1581-1587. [CrossRef]

132. Ihira, M.; Akimoto, S.; Miyake, F.; Fujita, A.; Sugata, K.; Suga, S.; Ohashi, M.; Nishimura, N.; Ozaki, T.; Asano, Y.; et al. Direct detection of human herpesvirus 6 DNA in serum by the loop-mediated isothermal amplification method. J. Clin. Virol. 2007, 39, 22-26. [CrossRef]

133. Liu, S.; Lin, Y.; Liu, T.; Cheng, C.; Wei, W.; Wang, L.; Li, F. Enzyme-free and label-free ultrasensitive electrochemical detection of DNA and adenosine triphosphate by dendritic DNA concatamer-based signal amplification. Biosens. Bioelectron. 2014, 56, 12-18. [CrossRef] 
134. Nie, J.; Zhang, D.W.; Tie, C.; Zhou, Y.L.; Zhang, X.X. G-quadruplex based two-stage isothermal exponential amplification reaction for label-free DNA colorimetric detection. Biosens. Bioelectron. 2014, 56, 237-242. [CrossRef] [PubMed]

135. Huang, J.; Wu, Y.; Chen, Y.; Zhu, Z.; Yang, X.; Yang, C.J.; Wang, K.; Tan, W. Pyrene-excimer probes based on the hybridization chain reaction for the detection of nucleic acids in complex biological fluids. Angew. Chem. Int. Ed. Engl. 2011, 50, 401-404. [CrossRef] [PubMed]

136. Wang, S.; Lifsond, M.A.; Incid, F.; Liang, L.-G.; Sheng, Y.-F.; Demircid, U. Advances in addressing technical challenges of point-of-care diagnostics in resource-limited settings. Expert Rev. Mol. Diagn. 2016, 16, 449-459. [CrossRef] [PubMed]

137. Farnaud, S.J.C.; Kosti, O.; Getting, S.J.; Renshaw, D. Saliva: Physiology and diagnostic potential in health and disease. Sci. World J. 2010, 10, 434-456. [CrossRef] [PubMed]

138. Deneer, H.G.; Knight, I. Inhibition of the Polymerase Chain Reaction by Mucolytic Agents. Clin. Chem. 1994, 40, 171-172. [PubMed]

139. Nolte, F.S.; Metchock, B.; Mcgowan, J.E.; Edwards, A.; Okwumabua, O.G.I.; Thurmond, C.; Mitchell, P.S.; Plikaytis, B.; Shinnick, T. Direct Detection of Mycobacterium tuberculosis in Sputum by Polymerase Chain Reaction and DNA Hybridization. J. Clin. Microbiol. 1993, 31, 1777-1782.

140. Aas, J.A.; Paster, B.J.; Stokes, L.N.; Olsen, I.; Dewhirst, F.E. Defining the Normal Bacterial Flora of the Oral Cavity Defining the Normal Bacterial Flora of the Oral Cavity. J. Clin. Microbiol. 2005, 43, 5721-5732. [CrossRef] [PubMed]

141. Shenai, S.; Armstrong, D.T.; Valli, E.; Dolinger, D.L.; Nakiyingi, L.; Dietze, R.; Dalcolmo, M.P.; Nicol, M.P.; Zemanay, W.; Manabe, Y.; et al. Analytical and clinical evaluation of the epistem genedrive assay for detection of mycobacterium tuberculosis. J. Clin. Microbiol. 2016, 54, 1051-1057. [CrossRef]

142. Shenai, S.; Amisano, D.; Ronacher, K.; Kriel, M.; Banada, P.P.; Song, T.; Lee, M.; Joh, J.S.; Winter, J.; Thayer, R.; et al. Exploring alternative biomaterials for diagnosis of pulmonary tuberculosis in HIV-negative patients by use of the geneXpert MTB/RIF assay. J. Clin. Microbiol. 2013, 51, 4161-4166. [CrossRef]

143. Theron, G.; Peter, J.; Calligaro, G.; Meldau, R.; Hanrahan, C.; Khalfey, H.; Matinyenya, B.; Muchinga, T.; Smith, L.; Pandie, S.; et al. Determinants of PCR performance (Xpert MTB/RIF), including bacterial load and inhibition, for TB diagnosis using specimens from different body compartments. Sci. Rep. 2014, 4, 5658. [CrossRef]

144. Boehme, C.C.; Pamela, N.; Hillemann, D.; Nicol, M.P.; Shenai, S.; Krapp, F.; Allen, J.; Tahirli, R.; Blakemore, R.; Rustomjee, R.; et al. Rapid Molecular Detection of Tuberculosis and Rifampin Resistance. N. Engl. J. Med. 2010, 363, 2373-2383. [CrossRef]

145. Yamamoto, N.; Hamaguchi, S.; Akeda, Y.; Santanirand, P.; Kerdsin, A.; Seki, M.; Ishii, Y.; Paveenkittiporn, W.; Bonomo, R.A.; Oishi, K.; et al. Clinical Specimen-Direct LAMP: A Useful Tool for the Surveillance of blaOXA-23-Positive Carbapenem-Resistant Acinetobacter baumannii. PLoS ONE 2015, 10, e0133204. [CrossRef] [PubMed]

146. Nuchprayoon, S.; Saksirisampant, W.; Jaijakul, S.; Nuchprayoon, I. Flinders technology associates (FTA) filter paper-based DNA extraction with polymerase chain reaction (PCR) for detection of Pneumocystis jirovecii from respiratory specimens of immunocompromised patients. J. Clin. Lab. Anal. 2007, 21, 382-386. [CrossRef]

147. Boehme, C.C.; Nabeta, P.; Henostroza, G.; Raqib, R.; Rahim, Z.; Gerhardt, M.; Sanga, E.; Hoelscher, M.; Notomi, T.; Hase, T.; et al. Operational feasibility of using loop-mediated isothermal amplification for diagnosis of pulmonary tuberculosis in microscopy centers of developing countries. J. Clin. Microbiol. 2007, 45, 1936-1940. [CrossRef] [PubMed]

148. Komatsu, H.; Imura, M.; Tateno, A.; Tsunoda, T.; Inui, A.; Sogo, T.; Fujisawa, T. Successful use of saliva without DNA extraction for detection of macrolide-resistant Mycoplasma pneumoniae DNA in children using LNA probe-based real-time PCR. J. Infect. Chemother. 2013, 19, 1087-1092. [CrossRef] [PubMed]

149. Gale, N.; French, D.J.; Howard, R.L.; McDowell, D.G.; Debenham, P.G.; Brown, T. Rapid typing of STRs in the human genome by HyBeacon melting. Org. Biomol. Chem. 2008, 6, 4553-4559. [CrossRef] [PubMed]

150. French, D.J.; Archard, C.L.; Andersen, M.T.; McDowell, D.G. Ultra-rapid DNA analysis using HyBeacon probes and direct PCR amplification from saliva. Mol. Cell. Probes 2002, 16, 319-326. [CrossRef] [PubMed] 
151. Yamagishi, J.; Sato, Y.; Shinozaki, N.; Ye, B.; Tsuboi, A.; Nagasaki, M.; Yamashita, R. Comparison of boiling and robotics automation method in DNA extraction for metagenomic sequencing of human oral microbes. PLoS ONE 2016, 11, e0154389. [CrossRef]

152. Lazarevic, V.; Gaïa, N.; Girard, M.; François, P.; Schrenzel, J. Comparison of DNA Extraction Methods in Analysis of Salivary Bacterial Communities. PLoS ONE 2013, 8, e67699. [CrossRef]

153. Lazarevic, V.; Whiteson, K.; Hernandez, D.; François, P.; Schrenzel, J. Study of inter- and intra-individual variations in the salivary microbiota. BMC Genom. 2010, 11, 523. [CrossRef]

154. Faveri, M.; Mayer, M.P.A.; Feres, M.; De Figueiredo, L.C.; Dewhirst, F.E.; Paster, B.J. Microbiological diversity of generalized aggressive periodontitis by $16 \mathrm{~S}$ rRNA clonal analysis. Oral Microbiol. Immunol. 2008, 23, 112-118. [CrossRef]

155. Du, Y.; Hughes, R.A.; Bhadra, S.; Jiang, Y.S.; Ellington, A.D.; Li, B. A Sweet Spot for Molecular Diagnostics: Coupling Isothermal Amplification and Strand Exchange Circuits to Glucometers. Sci. Rep. 2015, 5, 11039. [CrossRef] [PubMed]

156. Kirschner, P.; Rosenau, J.; Springer, B.; Teschner, K.; Feldmann, K.; Bottger, E.C. Diagnosis of mycobacterial infections by nucleic acid amplification: 18-month prospective study. J. Clin. Microbiol. 1996, 34, 304-312. [PubMed]

157. Ferguson, T.M.; Weigel, K.M.; Lakey Becker, A.; Ontengco, D.; Narita, M.; Tolstorukov, I.; Doebler, R.; Cangelosi, G.A.; Niemz, A. Pilot study of a rapid and minimally instrumented sputum sample preparation method for molecular diagnosis of tuberculosis. Sci. Rep. 2016, 6, 19541. [CrossRef] [PubMed]

158. Geojith, G.; Dhanasekaran, S.; Chandran, S.P.; Kenneth, J. Efficacy of loop mediated isothermal amplification (LAMP) assay for the laboratory identification of Mycobacterium tuberculosis isolates in a resource limited setting. J. Microbiol. Methods 2011, 84, 71-73. [CrossRef] [PubMed]

159. Aryan, E.; Makvandi, M.; Farajzadeh, A.; Huygen, K.; Bifani, P.; Mousavi, S.L.; Fateh, A.; Jelodar, A.; Gouya, M.M.; Romano, M. A novel and more sensitive loop-mediated isothermal amplification assay targeting IS6110 for detection of Mycobacterium tuberculosis complex. Microbiol. Res. 2010, 165, 211-220. [CrossRef]

160. Pandey, B.D.; Poudel, A.; Yoda, T.; Tamaru, A.; Oda, N.; Fukushima, Y.; Lekhak, B.; Risal, B.; Acharya, B.; Sapkota, B.; et al. Development of an in-house loop-mediated isothermal amplification (LAMP) assay for detection of Mycobacterium tuberculosis and evaluation in sputum samples of Nepalese patients. J. Med. Microbiol. 2008, 57, 439-443. [CrossRef]

161. Boyle, D.S.; McNerney, R.; Teng Low, H.; Leader, B.T.; Pérez-Osorio, A.C.; Meyer, J.C.; O'Sullivan, D.M.; Brooks, D.G.; Piepenburg, O.; Forrest, M.S. Rapid detection of Mycobacterium tuberculosis by recombinase polymerase amplification. PLoS ONE 2014, 9, e103091. [CrossRef] [PubMed]

162. Afghani, B.; Stutman, H.R. Polymerase chain reaction for diagnosis of M. tuberculosis: Comparison of simple boiling and a conventional method for DNA extraction. Biochem. Mol. Med. 1996, 57, 14-18. [CrossRef]

163. Kocagöz, T.; Yilmaz, E.; Ozkara, S.; Kocagöz, S.; Hayran, M.; Sachedeva, M.; Chambers, H.F. Detection of Mycobacterium tuberculosis in sputum samples by polymerase chain reaction using a simplified procedure. J. Clin. Microbiol. 1993, 31, 1435-1438.

164. Shawar, R.M.; el Zaatari, F.A.; Nataraj, A.; Clarridge, J.E. Detection of Mycobacterium tuberculosis in clinical samples by two-step polymerase chain reaction and nonisotopic hybridization methods. J. Clin. Microbiol. 1993, 31, 61-65. [PubMed]

165. Buck, G.E.; O'Hara, L.C.; Summersgill, J.T. Rapid, simple method for treating clinical specimens containing Mycobacterium tuberculosis to remove DNA for polymerase chain reaction. J. Clin. Microbiol. 1992, 30, 1331-1334. [PubMed]

166. Thomson, L.M.; Traore, H.; Yesilkaya, H.; Doig, C.; Steingrimsdottir, H.; Garcia, L.; Forbes, K.J. An extremely rapid and simple DNA-release method for detection of M. tuberculosis from clinical specimens. J. Microbiol. Methods 2005, 63, 95-98. [CrossRef] [PubMed]

167. Mitarai, S.; Okumura, M.; Toyota, E.; Yoshiyama, T.; Aono, A.; Sejimo, A.; Azuma, Y.; Sugahara, K.; Nagasawa, T.; Nagayama, N.; et al. Evaluation of a simple loop-mediated isothermal amplification test kit for the diagnosis of tuberculosis. Int. J. Tuberc. Lung Dis. 2011, 15, 1211-1217. [CrossRef] [PubMed]

168. Tarhan, G.; Ceyhan, I.; Şimşek, H.; Tuncer, S. Evaluation of the efficacy of five DNA extraction methods for the detection of Mycobacterium tuberculosis DNA in direct and processed sputum by an in-house PCR method. Turk. J. Med. Sci. 2009, 39, 253-257. 
169. Nihonyanagi, S.; Kanoh, Y.; Okada, K.; Uozumi, T.; Kazuyama, Y.; Yamaguchi, T.; Nakazaki, N.; Sakurai, K.; Hirata, Y.; Munekata, S.; et al. Clinical usefulness of multiplex PCR lateral flow in MRSA detection: A novel, rapid genetic testing method. Inflammation 2012, 35, 927-934. [CrossRef] [PubMed]

170. Mutingwende, I.; Vermeulen, U.; Steyn, F.; Viljoen, H.; Grobler, A. Development and evaluation of a rapid multiplex-PCR based system for Mycobacterium tuberculosis diagnosis using sputum samples. J. Microbiol. Methods 2015, 116, 37-43. [CrossRef]

171. Sjöbring, U.; Mecklenburg, M.; Andersen, A.B.; Miörner, H. Polymerase chain reaction for detection of Mycobacterium tuberculosis. J. Clin. Microbiol. 1990, 28, 2200-2204.

172. Sritharan, V.; Barker, R.H. A simple method for diagnosing M. tuberculosis infection in clinical samples using PCR. Mol. Cell. Probes 1991, 5, 385-395. [CrossRef]

173. Lunny, C.; Taylor, D.; Hoang, L.; Wong, T.; Gilbert, M.; Lester, R.; Krajden, M.; Ogilvie, G. Self-Collected versus Clinician-Collected Sampling for Chlamydia and Gonorrhea Screening: A Systemic Review and Meta-Analysis. PLoS ONE 2015, 10, e0132776. [CrossRef]

174. Thompson, P.P.; Kowalski, R.P.; Shanks, R.M.Q.; Gordon, Y.J. Validation of real-time PCR for laboratory diagnosis of Acanthamoeba keratitis. J. Clin. Microbiol. 2008, 46, 3232-3236. [CrossRef] [PubMed]

175. Goldschmidt, P.; Rostane, H.; Saint-Jean, C.; Batellier, L.; Alouch, C.; Zito, E.; Bourcier, T.; Laroche, L.; Chaumeil, C. Effects of topical anaesthetics and fluorescein on the real-time PCR used for the diagnosis of Herpesviruses and Acanthamoeba keratitis. Br. J. Ophthalmol. 2006, 90, 1354-1356. [CrossRef] [PubMed]

176. Wiedbrauk, D.L.; Werner, J.C.; Drevon, A.N.N.M. Inhibition of PCR by Aqueous and Vitreous Fluids. J. Clin. Microbiol. 1995, 33, 2643-2646.

177. Schläpfer, G.; Senn, H.P.; Berger, R.; Just, M. Use of the polymerase chain reaction to detect Bordetella pertussis in patients with mild or atypical symptoms of infection. Eur. J. Clin. Microbiol. Infect. Dis. 1993, 12, 459-463. [CrossRef] [PubMed]

178. Harding-Esch, E.M.; Holland, M.J.; Schémann, J.F.; Molina, S.; Sarr, I.; Andreasen, A.A.; Roberts, C.H.; Sillah, A.; Sarr, B.; Harding, E.F.; et al. Diagnostic accuracy of a prototype point-of-care test for ocular chlamydia trachomatis under field conditions in the Gambia and Senegal. PLoS Negl. Trop. Dis. 2011, 5, e1234. [CrossRef]

179. Sim, J.E.; Park, S.J.; Lee, H.C.; Kim, S.-Y.; Kim, J.Y.; Lee, S.H. High-throughput STR analysis for DNA database using direct PCR. J. Forensic Sci. 2013, 58, 989-992. [CrossRef] [PubMed]

180. Bell, J.; Bonner, A.; Cohen, D.M.; Birkhahn, R.; Yogev, R.; Triner, W.; Cohen, J.; Palavecino, E.; Selvarangan, R. Multicenter clinical evaluation of the novel Alere i Influenza A\&B isothermal nucleic acid amplification test. J. Clin. Virol. 2014, 61, 81-86.

181. Harty, L.C.; Rothman, N.; Reid, Y.A.; Tucker, M.A.; Hartge, P. Collection of Buccal Cell DNA Using Treated Cards. Cancer Epidemiol. Biomark. Prev. 2000, 9, 501-506.

182. Manage, D.P.; Lauzon, J.; Atrazhev, A.; Morrissey, Y.C.; Edwards, A.L.; Stickel, A.J.; Crabtree, H.J.; Pabbaraju, K.; Zahariadis, G.; Yanow, S.K.; et al. A miniaturized and integrated gel post platform for multiparameter PCR detection of herpes simplex viruses from raw genital swabs. Lab Chip 2012, 12, 1664-1671. [CrossRef]

183. Manage, D.P.; Lauzon, J.; Atrazev, A.; Chavali, R.; Samuel, R.A.; Chan, B.; Morrissey, Y.C.; Gordy, W.; Edwards, A.L.; Larison, K.; et al. An enclosed in-gel PCR amplification cassette with multi-target, multi-sample detection for platform molecular diagnostics. Lab Chip 2013, 13, 2576-2584. [CrossRef]

184. Sakai, K.; Wakasugi, S.; Muchemwa, F.C.; Ihn, H. Quick detection of herpes viruses from skin vesicles and exudates without nucleic acid extraction using multiplex PCR. Biosci. Trends 2008, 2, 164-168. [PubMed]

185. Pandori, M.W.; Lei, J.; Wong, E.H.; Klausner, J.; Liska, S. Real-Time PCR for detection of herpes simplex virus without nucleic acid extraction. BMC Infect. Dis. 2006, 6, 104. [CrossRef] [PubMed]

186. Loeffelholz, M.J.; Lewinski, C.A.; Silver, S.R.; Purohit, A.P.; Buonagurio, D.A.; Dragon, E.A. Detection of Chlamydia trachomatis in Endocervical Specimens by Polymerase Chain Reaction. J. Clin. Microbiol. 1992, 30, 2847-2851. [PubMed]

187. Manage, D.P.; Ma, L.; Lauzon, J.; Howell, A.; Belch, A.R.; Mackey, J.R.; Pilarski, L.M. Genotyping Single Nucleotide Polymorphisms in Human Genomic DNA with an Automated and Self-Contained PCR Cassette. J. Mol. Diagn. 2014, 16, 550-557. [CrossRef] [PubMed]

188. Grujičić, N.K.; Davidović, S.; Takić, D.; Mojsin, M.; Stevanović, M. Direct PCR amplification of the HVSI region in mitochondrial DNA from buccal cell swabs. Arch. Biol. Sci. 2012, 64, 851-858. [CrossRef] 
189. Lind-brandberg, L.; Welinder-olsson, C.; Taranger, J.; Trollfors, B.; Lagergård, T.; Zackrisson, G. Evaluation of PCR for Diagnosis of Bordetella pertussis and Bordetella parapertussis Infections These include: Evaluation of PCR for Diagnosis of Bordetella pertussis and Bordetella parapertussis Infections. J. Clin. Microbiol. 1998, 36, 679-683. [PubMed]

190. Kinchington, P.R.; Turse, S.E.; Kowalski, R.P.; Gordon, Y.J. Use of polymerase chain amplification reaction for the detection of adenoviruses in ocular swab specimens. Investig. Ophthalmol. Vis. Sci. 1994, 35, 4126-4134.

191. Tabrizi, S.N.; Lees, M.I.; Garland, S.M. Comparison of polymerase chain reaction and culture techniques for detection of Chlamydia trachomatis. Mol. Cell. Probes 1993, 7, 357-360. [CrossRef] [PubMed]

192. Howard, R.L.; French, D.J.; Richardson, J.A.; O’Neill, C.E.; Andreou, M.P.; Brown, T.; Clark, D.; Clarke, I.N.; Holloway, J.W.; Marsh, P.; et al. Rapid detection of diagnostic targets using isothermal amplification and HyBeacon probes-A homogenous system for sequence-specific detection. Mol. Cell. Probes 2014, 29, 92-98. [CrossRef]

193. Kobayashi, T.; Yagami, A.; Suzuki, K.; Ihira, M.; Yoshikawa, T.; Matsunaga, K. Clinical utility of loop-mediated isothermal amplification assay for the diagnosis of common alpha herpesvirus skin infections. J. Dermatol. 2013, 40, 1033-1037. [CrossRef]

194. Enomoto, Y.; Yoshikawa, T.; Ihira, M.; Akimoto, S.; Miyake, F.; Usui, C.; Suga, S.; Suzuki, K. Rapid Diagnosis of Herpes Simplex Virus Infection by a Loop-Mediated Isothermal Amplification Method. J. Clin. Microbiol. 2005, 43, 951-955. [CrossRef] [PubMed]

195. Okamoto, S.; Yoshikawa, T.; Ihira, M.; Suzuki, K.; Shimokata, K.; Nishiyama, Y.; Asano, Y. Rapid detection of varicella-zoster virus infection by a loop-mediated isothermal amplification method. J. Med. Virol. 2004, 74, 677-682. [CrossRef] [PubMed]

196. Wakabayashi, T.; Yamashita, R.; Kakita, T.; Kakita, M.; Oshika, T. Rapid and sensitive diagnosis of adenoviral keratoconjunctivitis by loop-mediated isothermal amplification (LAMP) method. Curr. Eye Res. 2004, 28, 445-450. [CrossRef] [PubMed]

197. Sun, Y.; Zhao, L.; Zhao, M.; Zhu, R.; Deng, J.; Wang, F.; Li, F.; Ding, Y.; Tian, R.; Qian, Y. Four DNA extraction methods used in loop-mediated isothermal amplification for rapid adenovirus detection. J. Virol. Methods 2014, 204, 49-52. [CrossRef] [PubMed]

198. Mahony, J.; Chong, S.; Bulir, D.; Ruyter, A.; Mwawasi, K.; Waltho, D. Development of a sensitive loop-mediated isothermal amplification assay that provides specimen-to-result diagnosis of respiratory syncytial virus infection in $30 \mathrm{~min}$. J. Clin. Microbiol. 2013, 51, 2696-2701. [CrossRef]

199. Mahony, J.; Chong, S.; Bulir, D.; Ruyter, A.; Mwawasi, K.; Waltho, D. Multiplex loop-mediated isothermal amplification (M-LAMP) assay for the detection of influenza A/H1, A/H3 and influenza B can provide a specimen-to-result diagnosis in 40min with single genome copy sensitivity. J. Clin. Virol. 2013, 58, 127-131. [CrossRef]

200. Nie, K.; Qi, S.X.; Zhang, Y.; Luo, L.; Xie, Y.; Yang, M.J.; Zhang, Y.; Li, J.; Shen, H.; Li, Q.; et al. Evaluation of a Direct Reverse Transcription Loop-Mediated Isothermal Amplification Method without RNA Extraction for the Detection of Human Enterovirus 71 Subgenotype C4 in Nasopharyngeal Swab Specimens. PLoS ONE 2012, 7, e52486. [CrossRef] [PubMed]

201. Ablordey, A.; Amissah, D.A.; Aboagye, I.F.; Hatano, B.; Yamazaki, T.; Sata, T.; Ishikawa, K.; Katano, H. Detection of Mycobacterium ulcerans by the loop mediated isothermal amplification method. PLoS Negl. Trop. Dis. 2012, 6, e1590. [CrossRef]

202. Iwata, S.; Shibata, Y.; Kawada, J.; Hara, S.; Nishiyama, Y.; Morishima, T.; Ihira, M.; Yoshikawa, T.; Asano, Y.; Kimura, H. Rapid detection of Epstein-Barr virus DNA by loop-mediated isothermal amplification method. J. Clin. Virol. 2006, 37, 128-133. [CrossRef]

203. Walker, G.T.; Little, M.C.; Nadeau, J.G.; Shank, D.D. Isothermal in vitro amplification of DNA by a restriction enzyme/DNA polymerase system. Proc. Natl. Acad. Sci. USA 1992, 89, 392-396. [CrossRef]

204. Lafleur, L.; Bishop, J.D.; Heiniger, E.K.; Gallagher, R.P.; Wheeler, M.D.; Kauffman, P.C.; Zhang, X.; Kline, E.; Buser, J.; Ramachandran, S.; et al. A rapid, instrument-free, sample-to-result nucleic acid amplification test. Lab Chip 2016, 52, 3377-3383. [CrossRef] [PubMed]

205. Rodriguez, N.M.; Linnes, J.C.; Fan, A.; Ellenson, C.K.; Pollock, N.R.; Klapperich, C.M. Paper-Based RNA Extraction, in Situ Isothermal Amplification, and Lateral Flow Detection for Low-Cost, Rapid Diagnosis of Influenza A (H1N1) from Clinical Specimens. Anal. Chem. 2015, 87, 7872-7879. [CrossRef] [PubMed] 
206. Tang, W.; Chow, W.H.A.; Li, Y.; Kong, H.; Tang, Y.-W.; Lemieux, B. Nucleic acid assay system for tier II laboratories and moderately complex clinics to detect HIV in low-resource settings. J. Infect. Dis. 2010, 201, S46-S51. [CrossRef]

207. Kim, H.-J.; Tong, Y.; Tang, W.; Quimson, L.; Cope, V.A.; Pan, X.; Motre, A.; Kong, R.; Hong, J.; Kohn, D.; et al. A rapid and simple isothermal nucleic acid amplification test for detection of herpes simplex virus types 1 and 2. J. Clin. Virol. 2011, 50, 26-30. [CrossRef] [PubMed]

208. Akduman, D.; Ehret, J.M.; Messina, K.; Ragsdale, S.; Judson, F.N. Evaluation of a strand displacement amplification assay (BD ProbeTec-SDA) for detection of Neisseria gonorrhoeae in urine specimens. J. Clin. Microbiol. 2002, 40, 281-283. [CrossRef]

209. Mahony, J.; Song, X.; Chong, S. NucliSens Basic Kit for Detection of Chlamydia trachomatis and Neisseria gonorrhoeaein Genital Tract Specimens Using Nucleic Acid Sequence-Based Amplification. J. Clin. Microbiol. 2001, 39, 1429-1435. [CrossRef] [PubMed]

210. Khan, G.; Kangro, H.; Coates, P.J.; Heath, R.B. Inhibitory effects of urine on the polymerase chain reaction for cytomegalovirus DNA. J. Clin. Pathol. 1991, 44, 360-365. [CrossRef]

211. McElgunn, C.J.; Pereira, C.R.; Parham, N.J.; Smythe, J.E.; Wigglesworth, M.J.; Smielewska, A.; Parmar, S.A.; Gandelman, O.A.; Brown, N.M.; Tisi, L.C.; et al. A low complexity rapid molecular method for detection of Clostridium difficile in stool. PLoS ONE 2014, 9, e83808. [CrossRef]

212. Al-soud, W.A.; Rådström, P. Effects of Amplification Facilitators on Diagnostic PCR in the Presence of Blood, Feces, and Meat Effects of Amplification Facilitators on Diagnostic PCR in the Presence of Blood, Feces, and Meat. J. Clin. Microbiol. 2000, 38, 4463-4470.

213. Humphries, R.M.; Uslan, D.Z.; Rubin, Z. Performance of clostridium difficile toxin enzyme immunoassay and nucleic acid amplification tests stratified by patient disease severity. J. Clin. Microbiol. 2013, 51, 869-873. [CrossRef]

214. Gyorke, C.E.; Wang, S.; Leslie, J.L.; Cohen, S.H.; Solnick, J.V.; Polage, C.R. Evaluation of Clostridium difficile fecal load and limit of detection during a prospective comparison of two molecular tests, the illumigene C. difficile and xpert C. difficile/epi tests. J. Clin. Microbiol. 2013, 51, 278-280. [CrossRef] [PubMed]

215. Viala, C.; Le Monnier, A.; Maataoui, N.; Rousseau, C.; Collignon, A.; Poilane, I. Comparison of commercial molecular assays for toxigenic Clostridium difficile detection in stools: BD GeneOhm Cdiff, XPert C. difficile and illumigene C. difficile. J. Microbiol. Methods 2012, 90, 83-85. [CrossRef] [PubMed]

216. Pancholi, P.; Kelly, C.; Raczkowski, M.; Balada-Llasat, J.M. Detection of toxigenic Clostridium difficile: Comparison of the cell culture neutralization, Xpert C. difficile, Xpert C. difficile/Epi, and Illumigene C. difficile assays. J. Clin. Microbiol. 2012, 50, 1331-1335. [CrossRef]

217. Pasternack, R.; Vuorinen, P.; Miettinen, A. Evaluation of the Gen-Probe Chlamydia trachomatis transcription-mediated amplification assay with urine specimens from women. J. Clin. Microbiol. 1997, 35, 676-678. [PubMed]

218. Krõlov, K.; Frolova, J.; Tudoran, O.; Suhorutsenko, J.; Lehto, T.; Sibul, H.; Mäger, I.; Laanpere, M.; Tulp, I.; Langel, Ü. Sensitive and rapid detection of Chlamydia trachomatis by recombinase polymerase amplification directly from urine samples. J. Mol. Diagn. 2014, 16, 127-135. [CrossRef]

219. Al-Talib, H.; Latif, B.; Mohd-Zain, Z. Pentaplex PCR assay for detection of hemorrhagic bacteria from stool samples. J. Clin. Microbiol. 2014, 52, 3244-3249. [CrossRef] [PubMed]

220. Lantz, P.G.; Matsson, M.; Wadström, T.; Rådström, P. Removal of PCR inhibitors from human faecal samples through the use of an aqueous two-phase system for sample preparation prior to PCR. J. Microbiol. Methods 1997, 28, 159-167. [CrossRef]

221. Moore, M.D.; Jaykus, L.-A. Development of a Recombinase Polymerase Amplification Assay for Detection of Epidemic Human Noroviruses. Sci. Rep. 2017, 7, 40244. [CrossRef]

222. Nixon, G.J.; Svenstrup, H.F.; Donald, C.E.; Carder, C.; Stephenson, J.M.; Morris-Jones, S.; Huggett, J.F.; Foy, C.A. A novel approach for evaluating the performance of real time quantitative loop-mediated isothermal amplification-based methods. Biomol. Detect. Quantif. 2014, 2, 4-10. [CrossRef]

223. Edwards, T.; Burke, P.A.; Smalley, H.B.; Gillies, L.; Hobbs, G. Loop-mediated isothermal amplification test for detection of Neisseria gonorrhoeae in urine samples and tolerance of the assay to the presence of urea. J. Clin. Microbiol. 2014, 52, 2163-2165. [CrossRef] 
224. Hill, J.; Beriwal, S.; Chandra, I.; Paul, V.K.; Kapil, A.; Singh, T.; Wadowsky, R.M.; Singh, V.; Goyal, A.; Jahnukainen, T.; et al. Loop-mediated isothermal amplification assay for rapid detection of common strains of Escherichia coli. J. Clin. Microbiol. 2008, 46, 2800-2804. [CrossRef] [PubMed]

225. Tang, Y.W.; Procop, G.W.; Persing, D.H. Molecular diagnostics of infectious diseases. Clin. Chem. 1997, 43, 2021-2038. [PubMed]

226. Dvorin, N. The Global Molecular Diagnostics Market Report \#A344; Medtech Insight: New York, NY, USA, 2015.

227. Peeling, R.W.; Mabey, D. Point-of-care tests for diagnosing infections in the developing world. Clin. Microbiol. Infect. 2010, 16, 1062-1069. [CrossRef] [PubMed]

228. Lee, H.H.; Dineva, M.A.; Chua, Y.L.; Ritchie, A.V.; Ushiro-Lumb, I.; Wisniewski, C.A. Simple amplification-based assay: A nucleic acid-based point-of-care platform for HIV-1 testing. J. Infect. Dis. 2010, 201, S65-S72. [CrossRef] [PubMed]

(C) 2019 by the authors. Licensee MDPI, Basel, Switzerland. This article is an open access article distributed under the terms and conditions of the Creative Commons Attribution (CC BY) license (http://creativecommons.org/licenses/by/4.0/). 